\title{
Pleistocene-Holocene Monogenetic Volcanism at Malko-Petropavlovsk Zone of Transverse Dislocations on Kamchatka: Geological Setting, Spatial, Geochemical Paticular Features and Potential Volcanic Hazards
}

\section{Olga Bergal-Kuvikas ( $\nabla$ kuvikas@mail.ru )}

Institute of Volcanology and Seismology FEB RAS: Institut vulkanologii i sejsmologii DVO RAN https://orcid.org/0000-0003-0079-507X

\section{llya Bindeman}

\section{University of Oregon}

\section{Andrey Chugaev}

Institute of Geology of Ore Deposits Petrography Mineralogy and Geochemistry RAS: Institut geologii rudnyh mestorozdenij petrografii mineralogii i geohimii RAN

Yulia Larionova

Institute of Geology of Ore Deposits Petrography Mineralogy and Geochemistry RAS: Institut geologii rudnyh mestorozdenij petrografii mineralogii i geohimii RAN

\section{Alexander Perepelov}

A P Vinogradov Institute of Geochemistry SB RAS: FGBUN Institut geohimii im A P Vinogradova Sibirskogo otdelenia Rossijskoj akademii nauk

\section{Olga Khubaeva}

Institute of Volcanology and Seismology FEB RAS: Institut vulkanologii i sejsmologii DVO RAN

\section{Research Article}

Keywords: origin of monogenetic volcanoes, Malko-Petropavlovsk zone of the transverse dislocation, Kamchatka, transform fault, Sr-Nd-Pb isotopic data

Posted Date: June 9th, 2021

DOI: https://doi.org/10.21203/rs.3.rs-584115/v1

License: (c) (i) This work is licensed under a Creative Commons Attribution 4.0 International License. Read Full License 


\title{
Pleistocene-Holocene monogenetic volcanism at Malko-Petropavlovsk zone of transverse dislocations on Kamchatka: geological setting, spatial, geochemical paticular features and potential volcanic hazards
}

\author{
Olga Bergal-Kuvikas ${ }^{* 1,2,3,4}$, Ilya Bindeman ${ }^{3,5}$, Andrey Chugaev $^{2}$, Yulia Larionova ${ }^{2}$, Alexander Perepelov ${ }^{6}$, Olga Khubaeva ${ }^{1,4}$
}

${ }^{1}$ Institute of Volcanology and Seismology FEB RAS, Petropavlovsk-Kamchatsky, 683006, Russia

${ }^{2}$ Institute of Geology of Ore Deposits, Petrography, Mineralogy and Geochemistry RAS, Moscow, 119017, Russia

${ }^{3}$ Fersman Mineralogical Museum RAS, Moscow, 115162, Russia

${ }^{4}$ Schmidt Institute of Physics of the Earth, Russian Academy of Sciences RAS, Moscow, 123242 Russia

${ }^{5}$ Dept. of Earth Sciences, 1272 University of Oregon, Eugene, OR 97403, USA

${ }^{6}$ Vinogradov Institute of Geochemistry SB RAS, Irkutsk, 664033, Russia

*Corresponding author: kuvikas@mail.ru

\section{Abstract}

Based on government statistical data $\sim 80 \%$ of the local Kamchatkan population ( $\sim 250$ ka people) live in the major cities on the coastal line of Avacha Gulf. It is the main transport seaway to Kamchatka, and and important Asia - North America air transport corridor. The Avacha Gulf is located in the Malko-Petropavlovsk zone of transverse dislocations (MPZ) on the extension of deep transform fault on the boundary between variously aged slabs. Most of monogenetic cinder cones chaotic distributed in relation to the trench and belong to the long-living rupture zones of MPZ. Some of the monogenetic volcanoes are parasitic cones on the slopes of Koryaksky and Avachinsky stratovolcanoes and related with their magma plumbing systems. We here present new results of the geochemical and isotopic studies of monogenetic volcanism in MPZ. Based on whole rock and trace element geochemistry, $\mathrm{Sr}-\mathrm{Nd}-\mathrm{Pb}$ isotopic ratios of monogenetic volcanism, magmas were shown to sample the enriched mantle source with dominance decompression melting without significant inputs of the slab's components. Calculations of the P, T conditions suggest magma residence of monogenetic cinder cones on the Moho boundary. That correlates with the geophysical observation of crustal discontinuity under the MPZ. Monogenetic cinder cones have an active magma plumbing system because during the Holocene time were several periods of activations. Presented results show necessary install continuous monitoring of environment changing around the Avacha Gulf and more serious attention from government and science. A more detailed investigation of MPZ will help degrease potential risks of eruptions from monogenetic volcanoes for human and infrastructures.

Keywords: origin of monogenetic volcanoes, Malko-Petropavlovsk zone of the transverse dislocation, Kamchatka, transform fault, $\mathrm{Sr}-\mathrm{Nd}$-Pb isotopic data

\section{Introduction}

The volcanism in island arcs settings is a dominant mechanism for formation crust in continental margins. Since initiation of plate tectonics, the island arcs formed, migrated and accreted to the continents (Ben-Avraham et al., 1981). These processes constitute complicated structures of the geological settings along the continental margins worldwide and North-Western Pacific in particular (Khanchuk et al., 2016; Konstantinovskaya, 2011). Modern volcanic fronts are superimposed on these preexisting structures, and their distribution is controlled by the depth to the slab, and crustal structures in the overriding plate. In addition, suprasubduction monogenetic volcanism is one of the indicators of deep inner process on the slab, mantle wedge and stress regime in the crust is a valuable tool for understanding magma genesis and evolution (Emelyanova and Lelikov, 2013; Gazel et al., 2009; Nakamura, 1980). Monogenetic volcanism is distributed widely and commonly represents the evolution of stress regimes around the individual stratovolcanos (Nemeth, 2010), but arc-pependicular and arc parallel linear trends of distributions of other cinder cones could be features of regional faults (Barbe-Cabusson, 2014; Maccaferri et al., 2015; Pardo et al., 2009). Monogenetic volcanic fields are not easy to forecast because they commonly appear at unexpected locations (sometimes using unknown faults). Likewise, the magma migrates radially or concentrically inside the earth's crust due to stress regime caused by inflating or deflating magmatic batches (Marti et al., 2016). Based on compilations of geophysical and 
geochemical data, Albert with coauthors (2016) show that seismic activity may start one or two years before the eruption of the monogenetic volcano, but it intensifies to warning levels approximately only two or three months or even one or two weeks before the eruption. Multiple magma batches can interact in a subvolcanic reservoir, and numerous intrusions occurred on similar time scales to the resulting seismicity and gas emanation according to the seismic, petrological and geochemical monitoring. The observations listed above suggest that the study of monogenetic volcanism is essential for understanding the neighbourhood of bigger stratovolcanoes, as well as deep structure of island arcs, regional faults, and the heterogeneity of the crust. From the volcanic hazards perspective and given that, commonly chaotic distributions of monogenetic volcanoes testify for necessity investigates the process of the structural control of their distribution as well as mechanisms of magma formations and evolutions, especially in high human density areas. This is particularly true since ascending magma in monogeneic eruptions may rupture at any area within a city with little warning.

Our research focuses on MPZ in Kamchatka Peninsula, eastern Russia and specifically on the coastline of Avacha Gulf (Fig. 1), where the capital city of Petropavlovsk and its satellites are located. It is the natural boundary between volcanic belts with various history of formation and active faults system, as well as massive stratovolcanoes such as Avachinsky, Vilyuchinsky, Koryaksky. The study's primary goal is to draw attention, describe distribution, and investigate the origin of monogenetic volcanism in this area from the volcanic hazards perspective. This research will be necessary for the local population and understand the cities' strategy in the future.

\section{Geodynamic and geological settings}

The geodynamic setting of Kamchatka in the Northernwest Pacific Ring of Fire transpacific subduction belt on the north of Kamchatka formed by the accretions of Late Cretaceous Achaivayam-Valagin arc terraine to the Eurasion margin at Early Eocene, 50 Ma (Chekhovich and Sukhov, 2006, Hourigan et al. 2009; Bindeman et al. 2002) and then Campan-Eocene Kronotsky arc terraine (Tsukanov et al., 2014) accreated to Kamchatka 10-6 Ma (Levashova et al., 2000), 7-10 Ma (Lander, Shapiro, 2007). The volcanism of Southern Kamchatka and the Kuriles has occurred under steady-state subduction conditions since the Miocene (Avdeiko et al., 2006). MPZ locats on the trajectory of the deep transform fault, which is called Avachinsky (Andreev, 1993) and was formed due to the long evolution of the north-west Pacific convergent margin (Seliverstov, 2009) (Fig. 1a). It still fixed on the continental slope (Popruzhenko, Zubin, 1997). Deep transform fault can be considered as a boundary between various aged slabs. The subducting Pacific slab ages under the Eastern volcanic belt are 100-105 Ma, under Southern Kamchatka are 89-92 Ma (Syracuse, Abers, 2006) (Fig. 1 a). Based on seismic data under the MPZ was fixed low-velocity anomaly (Gontovaya et al., 2010). Deep earthquakes are on Southern Kamchatka, Kuriles and absent them on the north from MPZ make a natural boundary of Kamchatka arc (Moroz, Gontovaya, 2018). On the Earth's surface MPZ detected by large fracture zone, which are orthogonal to the present location of the subduction zone (Kozhurin et al., 2008) (Fig. 1b). At least four regional faults are visible on the surface (Geological map..., 2000) (Fig. 1b, Suppl. 3). Based on geophysical observations upper crust of MPZ are fractured by numerous ruptures zones (Nurmukhamedov, Sidorov, 2019; Sheimovich, Sidorov, 2000), which are formed basement heterogeneity (Moroz, Gontovaya, 2018). A regular geodetic network at MPZ shows superintensive fault movements, which suggest active faults systems (Churikov, Kuzmin, 1998). Avacha Gulf located in MPZ and has a tectonic origin (Aprelkov, Svyatlovsky, 1989). Based on geological mapping, the anomaly area with perpendicular trench oriented geological formations and a faults of MPZ was first described in the entire monograph "Geology of USSR" (1964). The formation time of MPZ is Cenozoic (Shantser, 1987), but modern view started formed in the Late Miocene-Pliocene (Aprelkov et al., 1999; Dmitriev, Ezhov, 1977). Evolving extentional, compressional, then strike slip deformation along the MPZ has resulted in formation of the arc-perpendicular graben-like structure filled with hundreds of meters sediment derived from wide areas of Kamchatka (Geological map..., 2002; Sheimovich and Sidorov, 2000). In the area of its connection with the Sredinny range resulted in recent tectonic exhumation of high-grade amhibolites to granulate Ganal metasediments, representing the basement of the arc with ages of 18-80 Ma (Bindeman et al. 2002). Geophysical researches using the earthquake converted-wave method and magnetotelluric sounding suggest fragmentations of the crust and intrusions of magmatic bodies in various depths inside the MPZ 
3 (Nurmukhamedov, Sidorov, 2019). The high heat flow $\left(\sim 80 \mathrm{mVt} / \mathrm{m}^{2}\right)$ measurements in MPZ, while in the surrounding area is 40$460 \mathrm{mVt} / \mathrm{m}^{2}$ (Sugrobov, Yanovsky, 1991). The finding of alkalic and sub alkalic rock in the frontal zone in MPZ enabled some of 5 the researchers to suggest about unusual subduction origin of the Miocene magmas (Mitichkin et al., 1998; Baluev et al., 1984; 5 Sheimovich et al., 2005).

Volcanism in MPZ occurs in two types: along the polygenic stratovolcanoes with parasitic cones on the slopes and numerous independent monogenetic cinder cones, e.g. extrusive domes (Fig. 2b, 3d) (Supplementary 1). Stratovolcanoes include Koryaksky and Avachinsky volcanoes with known historic eruptions and volcanoes Kozelsky, Vilyuchinsky volcanoes without known historic eruptions. Most of the cinder cones concentrate in Paratunka and Bolshoy Vilyui rivers valleys (Fig. 1b, 2a, 3). According to Favorskaya with co-authors (1965), monogenetic cinder cones mark the long-living faults of MPZ. The basaltic cinder cones are localized in the boundaries of acid granitic intrusions and content granitic clasts inside the lava flows (Aprelkov,

3 Borzova, 1963). Monogenic cinder cones in the valley of the Paratunka river were formed in two stages: 8-10 ka BP and 2.4-3.6 4 ka BP. Volumes of Early Holocene pyroclastic materials are $\sim 0.08 \mathrm{~km}^{3}$ and $\sim 0.065 \mathrm{~km}^{3}$ of Late Holocene magmas (Dirksen, 5 2009). In the south part of Avacha Gulf is an isolated island near Vilyuchinsk city (Fig. 1, 2c). This is a cinder cone with basaltic magmas. Volume of the cone is less than 3-4 km³ (Dubik, Ogorodov, 1970). Cinder cones on the north of Avacha Gulf are parasitic cones of Koryaksky and Avachinsky volcanoes (Fig. 1). Only one isolated cinder cone located on the beach near 3 Petropavlovsk-Kamchatsky city. According to personal communication with Melekestsev I.V., in the mid-1970 years, it was some activity fixed there. People felt gas emission and heard some crackles. Not surprising, this cinder cone located mainly on the regional fault (Fig. 1b). This regional fault is a margin of the Avachinsky graben (Fig. 1c, 13) and well detected by geophysical data (Nurmukhamedov, Sidorov, 2019), basement heterogenity (Sheimovich, Sidorov, 2000), geological observations (Aprelkov et al., 1999; Geological map..., 2000) (Suppl. 3).

Extrusive domes mainly localized on the north of MPZ. One of the best examples is Mishennaya (Target) Mountain (Fig. $2 \mathrm{~b}, 3 \mathrm{~d}$ ). It is the extrusive dome with a diameter in the basement $\sim 1 \times 2 \mathrm{~km}$ (Sheimovich et al., 2007). It is a landmark hill with $385 \mathrm{~m}$ in altitude in downtown Petropavlovsk-Kamchatsky city with a viewpoint and TV station, while its slopes are covered with residential and government buildings (Fig. 2 d). Areal extent of the Mishennaya dome is estimated as $0,3 \mathrm{~km}^{2}$ (Grib, 1985). The exposed thickness of andesitic rocks is $50-70 \mathrm{~m}$ on the northern slope of the cone, the flanks are covered with sedimentary rock of Late Cretaceouc Nikolskaya suite (Sheimovich et al., 2007), with xenoliths of sedimentary rocks present in the base of the intrusion (Grib, 1985)-Age of the Mishennaya Mountain according to fission-track analyses is $700 \pm 200 \mathrm{ka}$ (Geological map., 2000) and $600 \pm 200$ ka was obtained by K-Ar dating of hornblendes (Sheimovich et al., 2007). All other extrusive domes north of 1 MPZ are re-covered by debris avalanche of Avachinsky volcano, which occurred 30 ka BP (Ponomareva et al. 2006). These 2 presense of andesitic extrusive domes, similar to Mt. Mishennaya were determined by geophysical methods and in drill cores 3 (Dmitriev, Ezhov, 1977; Geological map.., 2000; Svyatlovsky, 1956). According to the Geological map... (2000), the ages of 4 their formations range from 10 to $110 \mathrm{ka}$ BP determined by geological relantionship with surrounding rocks.. Because extrusive domes are particular visible on the area with covered deposits of the debris avalanche from Avachinsky volcano $(\sim 30$ ka BP formation according to Ponomareva et al., 2006) their ages estemates are older than Holocene. A massive extrusive dome was also identified under the water on the north part of the Avacha Gulf (Dmitriev, Ezhov, 1977). We therefore indicate that a simple compilation of existing data for domes similar to Mt. Mishennaya identify their wide-spread abundance requiring dedicated effort $\exists$ to determine their age, mode of emplacement and composition, as well as relation (or lack of it) to the other stratovolcanoes in the J area, an attempt that we initiate in this study.

\section{Samples and analytical methods}

In this study, we have collected $\sim 35$ samples of Pleistocene-Holocene magmatic rocks. The sampling localities are shown in Fig. 1 and listed in Supplementary 2. These include lava flows, bombs and lapilli of monogenetic cinder cones and fully crystalline andesites of Mishennaya extrusive dome. Thin sections were prepared and examined in the Institute of Volcanology 
and Seismology (IVS) in Petropavlovsk Kamchatky and Institute of Geology of Ore Deposits (IGEM) in Moscow, using Olympus $7 \quad$ BX51 polarizing microscope.

The whole-rock chemistry was studied on an Axios $\mathrm{mAX}$ vacuum wavelength dispersive XRF spectrometer (PANalytical Company (Netherlands)) at the Analytical center IGEM. The measurement accuracy was controlled by international standard samples BCR-2 and BIR-1. The analytical uncertainty was approximately $5 \%$ for the element whose contents in the samples were no higher than $0.5 \mathrm{wt} \%$. The trace element compositions were analyzed via inductively coupled plasma mass spectrometry (ICP-MS), using NEXION 300D in the Vinogradov Institute of Geochemistry, Irkutsk, Russia. The analytical uncertainties were estimated from the systematic analysis of the BHVO-2, AGV-2 rocks and calculated less than 10\%.

The high-precision MC-ICP-MS method (Rekhämper, Halliday, 1998) was used in this study for analysis of $\mathrm{Pb}$ isotope compositions in volcanic rocks, using the approach described in detail (Chernyshev et al., 2007). Analyses of $\mathrm{Pb}$ isotope ratios were carried out on a NEPTUNE mass-spectrometer (Thermo Scientific, Germany) at the Laboratory of Isotope Geochemistry and Geochronology IGEM. For analysis, $0.04-0.06 \mathrm{~g}$ of the whole rock powder was taken. Samples were dissolved in an $\mathrm{HNO}_{3}+$ $\mathrm{HF}(1: 3)$ mixture for two days at $140^{\circ} \mathrm{C}$. Subsequently, the solution was evaporated to dry salts. Separation of $\mathrm{Pb}$ from major and trace rock elements was carried out employing a one-step scheme with $\mathrm{HBr}$ medium in a chromatographic microcolumn $(0.1 \mathrm{~cm} 3)$ filled with anion exchange resin AG-1 $\times 8$ (Chugaev et al., 2013). The blank laboratory contribution for Pb did not exceed $0.1 \mathrm{ng}$. Before isotope analysis, the $\mathrm{Pb}$ solutions $\left(3 \% \mathrm{HNO}_{3}\right)$ were preliminarily traced by $\mathrm{Tl}$. Mass-bias correction for the measured $\mathrm{Pb}$ isotope ratios was performed using the reference ratio ${ }^{205} \mathrm{Tl} /{ }^{203} \mathrm{Tl}=2.3889 \pm 1$ employing an exponential law. Precision and accuracy of the results were monitored by systematic analyses of the SRM 981 and referenced andesite sample AGV-2. In a series of parallel analyses $(\mathrm{n}=4)$, average value of $\mathrm{Pb}$ isotope ratios were for AGV-2: ${ }^{206} \mathrm{~Pb} /{ }^{204} \mathrm{~Pb}=18.871 \pm 5 ;{ }^{207} \mathrm{~Pb} /{ }^{204} \mathrm{~Pb}=15.621 \pm$ $4 ;{ }^{208} \mathrm{~Pb} /{ }^{204} \mathrm{~Pb}=38.548 \pm 10$. The total error $( \pm 2 \mathrm{SD})$ of analysis for $\mathrm{Pb}$ did not exceed $\pm 0.03 \%$.

The Nd-Sr isotopic studies were carried out using a Sector 54 mass-spectrometer (Micromass), using a multi-dynamic mode routine at the Laboratory of Isotope Geochemistry and Geochronology IGEM (Larionova et al. 2007). The effects of massfractionation were corrected using an exponential law, via normalizing to ${ }^{86} \mathrm{Sr} /{ }^{88} \mathrm{Sr}=0.1194,{ }^{146} \mathrm{Nd} /{ }^{144} \mathrm{Nd}=0.7219$. The ${ }^{87} \mathrm{Sr} /{ }^{86} \mathrm{Sr}$ ratio of the SRM-987 Sr standard measured during the period of the analytical session averaged $0.710242 \pm 11( \pm 2 \mathrm{SD}, \mathrm{N}=10)$. The mean of the Nd-IGEM in-house Nd standard runs during the period of data collection was $0.512400 \pm 9$ for ${ }^{143} \mathrm{Nd} /{ }^{144} \mathrm{Nd}( \pm 2 \mathrm{SD}$, $\mathrm{N}=10$, which corresponds to LaJolla $\mathrm{Nd}$ standard ${ }^{143} \mathrm{Nd} /{ }^{144} \mathrm{Nd}=0.511850 \pm 9$ ).

Potential volcanic hazards were modelling using the support system for the online hazard assessment (VHASS) and risk mitigation created by Takarada, 2017.

\section{Results}

Fig. 4, 5 present results of our examination of monogeneic volcanic products in the MPZ based on geologic reports, maps, drilling summaries. Compiled from Russian literature of various age and often with limited circulations and tirazhes. We observed spatial and temporal distributions of monogenetic cinder cones and extrusive domes. Represanticive rock collection was selected. These samples have been analyzed for trace elemenets and isotopes and allow further geochemical analysis and discrimination. In particular, we are interested in exploring the clustering of monogeneic volcanism near existing stratovolcanoes and /or regional independent origin. We are interested in their connection to existing arc perpendicular fault structures. Finally, and more regionally, their relation to the overall subduction pattern and the depth to the slab.

\section{Spatial and temporal distributions of monogenic volcanism}

The geochemical features and spatial variations of volcanoes localitions in arcs settings correlate to slab depths, which should be enough to generate magma (Avdeiko et al., 2006; Duggen et al., 2007; Kimura, Yoshida, 2006 etc). To check the role of the subducting slab in generation volcanism in MPZ, the pattern of variations distance to trench with localization of volcanoes was created (Fig. 4). Stratovolcanoes are located from $\sim 213-230 \mathrm{~km}$ from the trench corresponding to depth over subduction zone of 88 to $107 \mathrm{~km}$ (Syracuse, Abers, 2006). Kozelsky and Vilyuchinsk volcanoes are frontal volcanoes. While Kozelsky volcano ( $\sim 88$ 
J km slab depth) and Avachinsky ( $\sim 94 \mathrm{~km}$ slab depth) and Koryaksky ( $\sim 107 \mathrm{~km}$ slab depth) are tracing arc perpendicular structure 1 (Fig. 4). Extrusive domes mainly are on the northern part of MPZ. Cinder cones focus on distance on $190 \mathrm{~km}$ and more to the 2 trench. Locations are chaotic and not dependent on the slab. But most of the cinder cones are concentrated on the southern part of 3 MPZ. One cinder cone is located on the Khalaktyrsky beach, on the marked boundary of Avachinsky graben (Fig. 1 b).

Geochronology for monogenetic cones is in urgent need for radiogenic dating. Current knowledge is based on relationship with geological suites and tephrachronology. All stratovolcanoes in MPZ start formed at least since the Late Pleistocene and were active until the Early Holocene (Aprelkov, Borzynkova, 1963; Masurenkov et al., 1991). Based on tephrochronology in early 7 Holocene (8-10 ka BP) on Vilchinsky and Kozelsky volcanoes were last eruptions (Krasheninnikov et al., 2020; Holocene..., 3 2020). Since that time, those volcanoes have not any volcanic activities. Koryaksky volcano was primarily active in the early 7 Holocene when the Avachinsky volcano was quiet. 2009 AD phreatomagmatic eruption in Koryaksky brought xenocrysts of J zircon and corundum filling the MPZ graben with ages 3400 to $1.8 \mathrm{Ma}$ (Bindeman et al 2016). Avachinsky volcano has two stages of volcano activities in Holocene. In the first stage (3.8-8 ka BP) were rare significant pumice eruptions, in opposite in the second 2 stage (3.8-present) frequent weak explosions with basaltic andesitic magma compositions (Krasheninnikov et al., 2020). 3 According to Geological map (2002) monogenetic cinder cones are presented young postglacial volcanism, which started active 4 since the early Holocene. Noteworthy is the possible link between activities of stratovolcanoes and activation of monogenetic cinder cones. In the early Holocene, after the final eruptions of Kozelsky and Vilyuchinsky, monogenetic volcanism started formation. Since $3.8 \mathrm{ka}$ BP changed the plumbing system of Avachinsky volcano, at the same time was fixed another activation of monogenetic volcanism (Fig. 5).

\section{Petrography and mineral assemblages}

The extrusive dome of Mn. Mishennaya andesites has fine-grained, phenocryst rich texture. $40-50 \%$ of the rocks are made of phenocrysts of plagioclases $(\mathrm{Pl})$, hornblendes $(\mathrm{Hbl})$. These are fully crystalline, not visicular rocks. Pls as Hbls have two generations with various sizes of the crystals. Generation A content Pls with $\sim 1000 \mu \mathrm{n}, \mathrm{Hbl} \sim 500 \mu \mathrm{n}$. Most of the crystals have regular shapes. Some of the Pls characterized by honey-comb structures. Generation B characterized by smaller sizes of crystals as Pls $\sim 500 \mu$ n, Hbls $\sim 100-200 \mu$ n. Crystalls of generations B are zoned crystals with regular structures. Microcrystals of the groundmass represented by sulphides (Fig. 6 a, b).

Samples of cinder cones near the Vilyuchinsk city (MPDZ-12a) have aphanitic, sometimes porphyritic textures (Fig. 5 c, d). Phenocrysts are olivines $(\mathrm{Ol})$, which are took $\sim 10 \%$ from whole rocks. The groundmasses are vesicular and content $\sim 30 \%$ of the bubbles. Groundmasses are glassy. The absence of microcrystals in the matrix could be interpreted as rapidly crystallization lava on or near the surface. Some of the thin sections were observed Pl microcrystals in groundmasses (Fig. $6 \mathrm{c}, \mathrm{d}$ ).

\section{Geochemistry and Sr-Nd- Pb isotopic ratios Major and Trace Elements}

Harker diagrams are presented on Fig. 7. Monogenetic cinder cones are basalts (50-52 wt.\% $\mathrm{SiO}_{2}$ ) with low alkaline contents (3.5-5 wt. $\% \mathrm{Na}_{2} \mathrm{O}+\mathrm{K}_{2} \mathrm{O}, 3.3-3.8 \mathrm{~N}_{2} \mathrm{O} / \mathrm{K}_{2} \mathrm{O}$ ). The extrusive dome of Mishennaya Mnt, is andesitic with 57-58 wt.\% $\mathrm{SiO}_{2}, 4-4.8$ wt.\% $\mathrm{Na}_{2} \mathrm{O}+\mathrm{K}_{2} \mathrm{O}, 4.4-5.2 \mathrm{~N}_{2} \mathrm{O} / \mathrm{K}_{2} \mathrm{O}$ (Fig. 7 a). Using Miyashiro's FeO/MgO diagram, almost all monogenetic cones belong to the tholeiitic series, same as an extrusive dome (Fig. 7 b). High $\mathrm{MgO}(\sim 6.5$ wt. \%) are characterise primitive magma of monogenetic cinder cones, opposite of extrusive dome with lower $\mathrm{MgO}$ contents ( 3 wt.\%) (Fig. 6 c). $\mathrm{Al}_{2} \mathrm{O}_{3}$ vary from 15 to 17 wt.\% for monogenetic cones and $\sim 18 \%$ for extrusive dome (Fig. 6 d). Trace element variations, especially Sr, has the highest $>450 \mathrm{ppm}$ values for basaltic monogenetic cinder cones and the lowest $(\sim 40 \mathrm{ppm})$ for more differentiated extrusive domes explained by plagioclase fractionation (Fig. 7 e). $\mathrm{Zr}$ variations are nearly the same (70-100 ppm) for cinder cones and extrusive domes (Fig. 7 f).

Trace element patterns of MPZ rocks normalised to primitive mantle have enriched large ion elements enrichment (e.g. Rb, $3 \mathrm{Ba}, \mathrm{Sr}$, and $\mathrm{Th}$ ) and depleted high field strength elements (e.g. Nb, Ta) (Fig. 8), typical for island arc origin. On chondrite 
normalised patterns of rare earth elements, the Eu anomalies are not observed (Fig. 9). The heavy REE elements with smaller ionic radius (e.g. $\mathrm{Lu}, \mathrm{Yb}, \mathrm{Tm}, \mathrm{Er}$ ) are near the same for all the rocks. In opposite are a slight enrichment of $\mathrm{La}, \mathrm{Ce}, \mathrm{Pr}, \mathrm{Ns}, \mathrm{Sm}$ for monogenetic cinder cones (Fig. 9a), Koryaksky (Fig. 9d) and Vilyuchinsky (Fig. 9 c) stratovolcanoes.

\section{$\mathrm{Sr}-\mathrm{Nd}-\mathrm{Pb}$ isotopes}

The Sr-Nd isotopic ratios vary within narrow ranges (Fig. 10 a). Monogenetic extrusive dome shows similar variations as rocks from Southern Kamchatka and Eastern volcanic belt. However, monogenetic cinder cones have lower "'Nd/“"Nd isotopic ratios, as variated " $\mathrm{Sr} / \mathrm{Sr}^{\mathrm{Sr}}$ isotopic ratios. The lower ${ }^{\prime \prime} \mathrm{Nd} /{ }^{\prime \prime} \mathrm{Nd}$ isotopic ratios could be interpreted as a contents slightly enrichment mantle component, like E-MORB (Fig. 10 a). The lead isotopic composition is the same as for rocks from the East volcanic belt and Southern Kamchatka (Fig. 10 b). The coefficient of variations for Pb isotopic ratios estimated as a $v(\%)$ are: $v_{\diamond u}=0.29, v_{\imath u}=$ 0.14 и $v_{\mathrm{su}}=0.20 \%$. The variations are relatively small, but are almost an order higher than the analytical error. Various aged rocks could not explain the revealed heterogeneity of the $\mathrm{Pb}$ isotopic composition in the rocks. Thus, estimated lead isotopic ratios reflect the primary process of magma genesis. Kamchatkan altered oceanic crust (K-AOC) and Kamchatkan subducted sediments (KSSC) were calculated by Duggan et al. (2007) and were compared with rocks from MPZ (Fig. 10 b). Variations of lead isotopes suggest that monogenetic volcanoes have similar variations with polygenic stratovolcanoes. However, range of variations monogenetic volcanoes are narrow $\left({ }^{m} \mathrm{~Pb} /{ }^{m} \mathrm{~Pb} \sim 18.30-18.45,{ }^{2 m} \mathrm{~Pb} /{ }^{m} \mathrm{~Pb} \sim 38.00-38.12\right)$ in comparing with polygenetic stratovolcanoes $\left({ }^{m} \mathrm{~Pb} / m \mathrm{~Pb} \sim 18.23-18.41, \cdots \mathrm{Pb} / m \mathrm{~Pb} \sim 37.98-38.17\right)$. Polygenetic stratovolcanoes, especially Koryaksky volcano show tendency to KSSC (Fig. 10 b).

\section{Discussion}

\section{Importance of study monogenetic volcanism for society}

The formation of monogenetic cinder cones in MPZ is interesting not only for researchers but also crucial for local populations. The deep $\sim 30 \mathrm{~km}$ (Moroz, Gontovaya, 2001) arc perpendicular regional faults form Avacha Gulf in the middle of Kamchatka's Pacific Coast (Fig. 1). It is one of the bigger such Gulfs s in the world, which is the main transport gateway to Kamchatka, and additionally most of the populations in Kamchatka live in main cities Petropavlovsk-Kamchatsky, Vilyuchinsk and Elizovo around this Gulf (Fig. 1). These cities are located within the MPZ faults and potentially could be affected by eruptions of monogenetic volcanoes, as well as seismic activity along these faults.

27 monogenetic volcanoes hat we identified and studied. Most of the ones are located in the southern part between latitudes 52.7 and $52.9 \mathrm{~N}$ and the average distribution density of monogentic cones per $\mathrm{km}^{2}$ is (Fig. 2). In the geologic time, it means that all MPZ areas, and especially its southern part have a potential to develop monogenetic volcanoes in the future. It is thus necessary to pay more attention to the MPZ. The government and scientists need to continue monitoring fault moving based on the existing and geodetic network and seismostations and install more in the future, to distinguish tectonic earthquakes along the fault and volcanically caused earthquakes. Fluctuation of gas chemistry in boreholes could be potentially helpful for the same purposes. Applying diverse geophysical methods: seismic, electromagnetic, gravity, as well as ground-surface moniroring using INSAR is necessary for better understanding the structure of the crust in the MPZ and detecting weak parts of fracture zones. In a parallel effort, geochemical and isotopically data on erupted products and microprobe analyses of phenocrysts enable determination of conditions of magma plumbing systems and differentiation in the crust and, in particular their volatile concentration. Future studies are necessary to 1) identify new cones, especially the ones under sedimentary cover and under Avacha Bay, 2) Date them using radiogenic methods, 3) predict the character and likelihood of future eruptions and their potential magnitude, duraction and impact, 4) gas release by these volcanoes, 5) alert local populations for likelihood of future eruption for the purpose of creating hazards map and for the purpose of insurance.

Local populations live in several cities within the broader area of the MPDS. Monogenetic volcanism also provides positive aspects to every day in daily life. Most monogenetic volcanoes were formed during the Holocene (Supplementary 1), and their cones are still preserved with a relative elevation of a few hundred meters. These high points and isolated islands are utilized as a basement for lighthouses in the Avacha Gulf, cell and radio-TV transmission stations (such as the ones on Mt. Mishennaya in 
downtown Petropavlovsk-Kamchatsky (Fig. 2). The elevated points offer recreational opportunities and vistas for the city, bay and

$J$ the ocean. Cinder cones on the coastline are quaried as road and construction material to build roads and structures, for example 1 the fish processing plants. One monogenetic cinder cones near the Vilyuchinsk city is a large factory specialising in the 2 development of gravels and sands.

3 The elevated grounds of local cinder cones provide shelter and escape routes for potential tsunami. This is especially important, because last $\sim 4200$ years were observed 33 tsunamis records on Khalaktyrsky beach (Pinegina et al., 2018).

Numerous dikes and sills were fixed at depth up to $7 \mathrm{~km}$ depths (Sheimovich, Sidorov, 2000). According to geophysical observations (Nurmukhamedov, Sidorov, 2019) the intrusive bodies intruded at the lower crust and not reached the surface. Drilling cores on the depths 600-1500 meters met with basic-intermediate compositions intrusive bodies and characterized by maximum water temperatures $\left(\sim 100^{\circ} \mathrm{C}\right)$ (Chudaev et al., 2016). According to geochemical and isotopic variations, the genesis of hot spring along the Paratunka river is the warming meteoric water (Chudaev et al., 2000). The highest heat flow $\left(\sim 80 \mathrm{mVt} / \mathrm{m}^{2}\right.$ according to Sugrobov, Yanovsky, 1991), which observed at MPZ argue with that hypothesis. Similarities of rare earth elements, 1 e.g. positive Eu anomaly in hot springs (Chudaev et al., 2000) and in magma compositions of monogenetic cinder cones (Fig. X), 2 enable assume the genetic link between them. dly open access online system for modelling the risk of volcanic activities. Important parameters for modeling are relative height $(\mathrm{H})$ of gravity flow and lateral travel distance $(\mathrm{L})$. The $\mathrm{H} / \mathrm{L}$ ratios were used 0.21 to 0.05 as a world range general parameter (Takarada, 2017). VHASS based on the Google Map. Positions of monogenetic volcanoes were obtained from Geological map (2000) (Fig. 11).

\section{Hazards to the population}

To estimate potential volcanic hazard from monogenetic cinder cones was used VHASS (Takarada, 2017). It is a userThe energy cone simulation results suggest that if the current monogenetic volcanoes would be active again, it would be produce block and lava flows. This is especially important for area with red color $(\mathrm{H} / \mathrm{L}>0.21)$ (Fig. $11 \mathrm{~b})$. However, risks of potential volcanic hazard would be distributed on the distance more than $10 \mathrm{~km}$ (pale pink color). The highest risks of potential volcanic dangerous are valley of Paratunka river, because there are the highest concentrations of monogenetic cinder cones (Fig. 11 b). The closest villages are Paratunka and Termalny with total population $\sim 3700$ men (Fig. 11 a). But in the valley of Paratunka river located development resorts with tourists and visitors. Additionally, along the Paratunka river is road, which is connected Mutnovskaya hydrothermal station and Tolmachevskaya hydrostation. For Vilyuchinsk city (population $\sim 23000$ men) more important is potential hazard from magma-water interactions, e.g. hydrothermal explosions. Because Khlebalkin isl. is an observed cinder cone in the Avacha Gulf, it means that at least in Holocene was volcanic activation. In downtown of the biggest city on Kamchatka the Petropavlovsk-Kamchatsky (population $\sim 180000 \mathrm{men}$ ) is suited Mishennaya extrusive dome. If the eruption would focus on the same place the risk for infrastructure and for human are very high, because main part of the city located in the slopes of Mishennaya Mount. Considering that one additinal extrusive dome is under water the exist risk of magmawater interaction, e.g. tsunami and changes of coastal line of Avacha Gulf. There are few cinder cones on the beach of Pacific ocean. These places have risks from magma-water interaction and it would be important because there are setlements and fishcathers companies (Fig. 11 b).

\section{Geochemical insights into the origin of monogenetic volcanism}

This work presented rich new analytical dataset for monogenetic volcanoes in an attempt to determine their origin. We interpret these data because it has direct implications on potential characher of magmatic eruptions.

Fluid-immobile elements are good indicators of the extent of melting process in the mantle wedge, as well as the degree of its prior melting/enrichment. The biggest $\mathrm{Nb}$-Ta minimums of the monogenetic cinder cones on spider diagrams indicate a different process for the magma origin from the polygenetic stratovolcanoes (Fig. 8a). The highest $\mathrm{Nb} / \mathrm{Yb}, \mathrm{Ti} / \mathrm{Yb}$ ratios on Pearce diagrams (Fig. 12 a, b) testify for enriched mantle source by E-MORB mantle. In contrast, extrusive dome and stratovolcanoes are derived 
from an N-MORB type of mantle. It is a good correlate with Sr-Nd isotopic ratios (Fig. 10 a, b), where monogenetic cinder cones have fewer $\mathrm{Nd}$ isotopic ratios, in contrast to extrusive dome and trends of Southern Kamchatka, Sredinny ridge and Eastern volcanic belt. The monogenetic cinder cones characterized by the highest contents of incompatible elements (e.g. $\mathrm{K}_{2} \mathrm{O}, \mathrm{Zr}, \mathrm{Sr}$ ) (Fig. 7). Variations of elements with the largest ionic radius (e.g. La, Ce, Pr, Nd) on the chondrite-normalized patterns could be interpreted as the various degree of partial melting in the wedge. In argue that correlations between those elements and isotopic variations of $\mathrm{Pb}$ isotopes are not observed. (Fig. $10 \mathrm{~d}$ ). As a rule in subduction zone setting, the degrees of partial melting decreases from the front to the rear arc zone (Churikova et al., 2001; Kimura, Yoshida, 2006). The Koryaksky stratovolcano localized in the rear arc and characterized by higher contents of rare earth elements (Fig. 9 d). Simultaneously, the frontal volcanoes are Avachinsky and Kozelsky have rocks with significant variations of $\mathrm{La}, \mathrm{Ce}, \mathrm{Sm}$ and etc (Fig. 9 e, f). This data cannot be explained by classical across-arc magma variations formed by different degrees of partial melting of an uniform mantle. In order to check melting regime we used ratios of $\mathrm{La} / \mathrm{Yb}, \mathrm{Ba} / \mathrm{La}, \mathrm{Nb} / \mathrm{Yb}$ (Fig. 13). Maximum $\mathrm{La} / \mathrm{Yb}$ correlate with minimum $\mathrm{Ba} / \mathrm{La}$ content for monogenetic volcanoes (Fig. 13a), which made difference from polygenetic volcanoes. Together changes of $\mathrm{Nb} / \mathrm{Ta}$ and $\mathrm{Ta}$ and the highest contents indicate for decompression melting for monogenetic volcanoes (Fig. $13 \mathrm{~b}$ ). Variations of fluidimmobile (Fig. 14 a, b) and mobile elements (Fig. 14 c, d) versus to distance to trench not show classical across arc variations. From the front to rear zone degrease contents of $\mathrm{Nb}$ and Ta (Fig. 14 a, b), but contents of Ba, Th (Fig. $14 \mathrm{c}, \mathrm{d}$ ) are near the same. Important to note, that Avachinsky and Koryaksky volcanoes characterized by classical across-arc variations with increasing contents of LREES and HFSE from front to rear arc zone. However, Kozelsky and Vilyuchinsky volcanoes are exceptions from that tendency. A possible explanation is the age of formation that volcanoes are much older than other stratovolcanoes. During the historical observations, they not show any activities since the Early Holocene (Fig. 5). Consequently, the degree of partial melting of Pleistocene activation of Kozelsky and Vilyuchinsky volcanoes was much lower than Holocene rocks of Avachinsky and Koryaksky volcanoes. The high contents of $\mathrm{Nb}, \mathrm{Ta}$ and other fluid-immobile elements of frontal volcanoes would be explained by a smaller degree of partial melting in the mantle wedge in begging of the formation stratovolcanoes in MPZ.

Ratios of fluid-mobile elements and $\mathrm{Pb}$ isotopes data were used for classified slab inputs on the Southern Kamchatka (Duggen et al., 2007) and Koryaksky, Avachinsky, Kozelsky stratovolcanoes (Krashenninikov et al., 2020). The highest valies of $7 \mathrm{Th} / \mathrm{Nd}$ (Fig. $12 \mathrm{c}, \mathrm{d}$ ) and ${ }^{206} \mathrm{~Pb} /{ }^{204} \mathrm{~Pb}$ ratios (Fig. $10 \mathrm{c}$, d) suggest sedimentary melts under the Koryaksky stratovolcano. This is a 3 common feature for rear arc volcanoes. In opposite, frontal volcanoes, e.g. Avachinsky, Kozelsky, and Mishennaya extrusive dome, have the higher $\mathrm{Ba} / \mathrm{Nb}, \mathrm{Sb} / \mathrm{Nb}$ ratios (Fig. 12 c, d). These testify for significant input of the shallow slab component, e.g. slab dehydration. Monogenetic cinder cones have remarkable lower fluid-mobile ratios than other volcanic rocks in MPZ (Fig. 12 c, d). Thus, contributions of the slab components to their genesis are minimum.

To estimate the depth of magma crystallization, the conditions of pressure and temperatures were obtained using glass thermometer Helts, Thoernber (1987) and glass barometer (Putirka, 2008) (Fig. 15). There are good correlations with petrologically estimated conditions and geophysical observations. Based on mantle tomography, the depth of the magma chamber under Koryaksky volcano is $\sim 7 \mathrm{~km}$, and there is a shallow magma reservoir on Avachinsky volcano at $\sim 2 \mathrm{~km}$ depth below the surface (Bushenkova et al., 2019). Our estimations show that the depths of magma chambers of stratovolcanoes are varying from 3-21 km (1 to 8 kbars) (Fig. 12). At depths of 12-15 km (4-5 kbars) parental magma of extrusive domes is estimated reside, the country rocks at these depths are represented by the basement of the Achaivayam-Valagin volcanic arc. The deepest magma plumbing systems are calculated for monogenetic cinder cones at 27-33 km (9-11 kbars) with the highest temperatures $\sim 1160^{\circ}$ $1240^{\circ} \mathrm{C}$ suggesting that the basaltic magmas are erupting directly from their storage conditions in the mantle or the Moho. These data have a reasonable correlation with depths of high electrical conductivity anomaly in MPZ (Moroz, Gontovaya, 2018) (Fig. 16). The absence of peripheral, shallow magma chambers suggests feeding of these deep reservoirs by regional faults (Fig. 1) that control the distribution of volcanism. Such faults were observed near the Vilyuchinsky volcano (Florensky, Bazanova, 1989; Sheimovich, Patoka, 2000). Sublimation of the fracture rocks was observed in the mantle xenoliths of the Avachinsky volcano (Sharapov et al., 2017). It was generated due to active seismic fragmentation in the lithospheric mantle wedge, on depths 30-70 $\mathrm{km}$ (Sharapov et al., 2020). Faults in MPZ are still active in the present time. According to geodetic network, during three years, 
observations on one of the active fault near the Petropavlovsk-Kamchatsky city ork were registered energy, i.e. seismicity and

3 "superintensive fault movements" along the fault (Churikov, Kuzmin, 1998).

\section{Conclusion}

1 This work draw attention on the spatial distribution and origin of monogenetic volcanism, most of Holocene age, in the MPZ, 2 inside or in proximity to major population centers on Kamchatka Peninsula. The combination of geological, geochemical and 3 geophysical data determine that high electrical conductivity anomaly in the crust (on 10-40 km depths according to Moroz, 7 Gontovaya, 2018) and low-velocity anomaly in the uppermost mantle correlate with the potential sources of Holocene monogenetic volcanism on the boundary between variously aged slabs on long-lived arc perpendicular transform fault. Trace element variations and isotopic data demonstrate that relatively enriched mantle source with minimum inputs of the slab's components is required to generate monogenetic cinder cones. They origin and chemical and isotopic composition are not so different than polygenic stratocones of Avachinsky, Vilyuchinsky and other volcanoes. However, highest contents of $\mathrm{Nb} / \mathrm{Yb}, \mathrm{Ta}$, and $\mathrm{La} / \mathrm{Yb}$ ratios testify for domination decompression melting in genesis of monogenetic volcanoes.

Most of monogenetic cinder cones trace the linear arc perpendicular rupture zones and their magmas are determined to ascent rapidly from the lower crust. As some cones have ages from $9.2 \mathrm{ka}$ to $2.4 \mathrm{ka}$ (Dirksen, 2009), there were several stages of activations on these rupture zones. Given relatively young Holocene age, it means that monogenetic cinder cones can still have an active magma plumbing system with geothermal potential. As most of the population of Kamchatka lives close to these monogenetic cinder cones and extrusive domes, it is necessary to set continuous monitoring using seismic data, ground deformation, gas, water analysis to predict potential dangers of volcanic hazard, and geothermal benefits from monogenetic volcanoes in the future.

\section{Acknowledgements}

Personal acknowledges are to Bazanova L.I., Dirksen O.V., Melekestsev I.V., Delemen I.F. for discussions and consultations of main structure of geological setting in MPZ. Thank you Kulish R., Uteshev I., Petrov O., Bergal V. for helping in organizations field works. We are thanking the grant 19-17-00241 of Russian Science Foundation for support of OB-K, IB, and megagrant of the Ministry of Education and Science of the Russian Federation (no. 14.W03.31.0033) for support of fieldworks.

\section{Conflict of interest}

The authors declare that they have no conflict of interest.

\section{Author contributions}

All authors contributed to the study conception and design. OB-K wrote the original draft. IB reviewed and edited the draft. CA prepared lead isotopes and improved interpretation of isotopic data. LY estimated Sr-Nd isotopic ratios. PA obtained trace elements geochemistry. KO worked with geophysical data and organized field works.

\section{Supplementary}

The list of monogenic cinder cones (Supplemenary 1), their geochemical, isotopic measurements (Supplementary 2) and demonstration of the genesis long-living transform fault under the MPZ (Supplementary 3) are available at Bergal-Kuvikas et al. (2021), "Monogenetic volcanism at Malko-Petropavlovsk zone of the transverse dislocation (Kamchatka)", Mendeley Data, V1, doi: 10.17632/8d69jr8yjv.1 https://data.mendeley.com/datasets/8d69jr8yjv/draft?a=33739679-5dee-4b10-9d3f-ded4d55e79b8 
Albert H., Costa F., Martí, J. (2016). Years to weeks of seismic unrest and magmatic intrusions precede monogenetic eruptions. Geology, 44(3), 211-214. https://doi.org/10.1130/G37239.1

Andreev A.A. (1993). Transform faults of the Earth`s crust, Northwestern Pacific. Pacific Geology. 3. P. 11-20 (in Russian).

Aprelkov S.E., Borzova G.P. (1963). Young volcanic structures around Avacha bay. Questions of geography of Kamchatka. 1. p. 34-40 (in Russian).

Aprelkov S. E., Ivanov B. V., Popruzhenko S. V. (1999). Tectonics and Geodynamic Evolution of Southeastern Kamchatka (Petropavlovsk Geodynamic Ground). Pacific geology. 18(4). P. 16-28 (in Russian).

Aprelkov S.Y., Svyatlovsky A.Y. (1989). The origin of Avacha Bay in Kamchatka. Pacific geology. 4. P. 108-111 (in Russian)

Avdeiko G. P., Palueva A. A., Khleborodova O. A. (2006). Geodynamic conditions of volcanism and magma formation in the Kurile-Kamchatka island-arc system. Petrology, 14(3), 230-246. https://doi.org/10.1134/S0869591106030027

Balyev E.Yu., Perepelov A.B., Ananev V.V., Taktaev B.N. (1984). High alkaly andesites in frontal part of island arc (Kamchatka). Report of Academy USSR. 274 (4). P. 977-981 (in Russian).

Barde-Cabusson, S., Gottsmann, J., Martí, J., Bolós, X., Camacho, A. G., Geyer, A., Sánchez, A. (2014). Structural control of monogenetic volcanism in the Garrotxa volcanic field (Northeastern Spain) from gravity and self-potential measurements. Bulletin of Volcanology, 76(1), 788. https://doi.org/10.1007/s00445-013-0788-0

Bazanova L.I., Puzankov M.Yu., Dirksen O.V., Kulich R.P., Kartasheva E.V. (2012). Lava flows of Koryaksky volcano in Holocene: success and problems of the dating. Materials of the annual volcanologist day «Volcanism and related process». Petropavlovsk-Kamchatsky. p.11-18 (in Russian).

Ben-Avraham, Z. V. I., Nur, A., Jones, D., Cox, A. (1981). Continental accretion: from oceanic plateaus to allochthonous terranes. Science, 213(4503), 47-54. DOI: 10.1126/science.213.4503.47

Bergal-Kuvikas, O., Leonov, V., Rogozin, A., Bindeman, I., Kliapitskiy, E., \& Churikova, T. (2019). Stratigraphy, structure and geology of Late Miocene Verkhneavachinskaya caldera with basaltic-andesitic ignimbrites at Eastern Kamchatka. Journal of Geosciences, (64), 229-250. DOI: 10.3190/jgeosci.295

Bergal-Kuvikas, Olga; Bindeman, Ilya; Chugaev, Andrey; Larionova, Yulia; Khubaeva, Olga; Perepelov, Alexander (2021), "Monogenetic volcanism at Malko-Petropavlovsk zone of the transverse dislocation (Kamchatka)", Mendeley Data, V1, doi: 10.17632/8d69jr8yjv.1

Bindeman, I.N., Anikin, L.P., Schmitt, A.K. (2016) Archean Xenocrysts in Modern Volcanic Rocks from Kamchatka: Insight into the Basement and Paleodrainage. Journal of Geology 124 (2), 247-253 https://doi.org/10.1086/684833

Bindeman, I. N.; Vinogradov, V. I.; Valley, J. W.; Wooden, J. L.; and Natalin, B. A. (2002). Archean protolith and accretion of crust in Kamchatka: SHRIMP dating of zircons from metamorphic rocks of Sredinny and Ganal Massifs. Journal of Geology 110:271-289. https://doi.org/10.1086/339532

Bushenkova, N., Koulakov, I., Senyukov, S., Gordeev, E. I., Huang, H. H., El Khrepy, S., \& Al Arifi, N. (2019). Tomographic images of magma chambers beneath the Avacha and Koryaksky volcanoes in Kamchatka. Journal of Geophysical Research: Solid Earth, 124(9), 9694-9713. https://doi.org/10.1029/2019JB017952

Chebrov V. N., Droznin D. V., Kugaenko Y. A., Levina V. I., Senyukov S. L., Sergeev V. A., Yashchuk V. V. (2013). The system of detailed seismological observations in Kamchatka in 2011. Journal of Volcanology and Seismology, 7(1), 16-36. https://doi.org/10.1134/S0742046313010028

Chekhovich, V. D., Sukhov, A. N. (2006). Breakup of the Late Cretaceous Achaivayam-Valagin volcanic arc in the Paleocene (terranes of southern Koryakia and eastern Kamchatka). Doklady earth sciences. Vol. 409, No. 2 , p. 893. DOI:10.1134/S1028334X06060122

Chernyshev, I.V., Chugaev, A.V., Shatagin, K.N., 2007. High-precision Pb isotope analysis by multicollector-ICP-massspectrometry using 205Tl/203 Tl normalization: optimization and calibration of the method for the studies of $\mathrm{Pb}$ isotope variations. Geochem. Int. 45, 1065-1076. https://doi.org/10.1134/S0016702907110018.

Chudaev O.V., Chudaeva V.A., Karpov G.A., Edmunds, Shand P. (2000). Geochemistry of water of the basic geothermal area of Kamchatka. Dalnauka. Vladivostok. P. 157 (in Russian).

Chudaev, O. V., Chelnokov, G. A., Bragin, I. V., Kharitonova, N. A., Rychagov, S. N., Nuzhdaev, A. A., \& Nuzhdaev, I. A. (2016). Geochemical features of major and rare-earth element behavior in the Paratunka and Bol'shebannyi hydrothermal systems of Kamchatka. Russian Journal of Pacific Geology, 10(6), 458-475. https://doi.org/10.1134/S1819714016060026

Chugaev, A.V., Chernyshev, I.V., Lebedev, V.A., Eremina, A.V., 2013b. Lead Isotope composition and origin of the quaternary lavas of Elbrus Volcano, the Greater Caucasus: high-precision MC-ICP-MS data. Petrology 21 , 16-27. https://doi.org/10.1134/S0869591113010037.

Churikov V. A., Kuzmin Y. O. (1998). Relation between deformation and seismicity in the active fault zone of Kamchatka, Russia. Geophysical Journal International, 133(3), 607-614. https://doi.org/10.1046/j.1365-246X.1998.00511.x

Churikova, T., Dorendorf, F., Wörner, G. (2001). Sources and fluids in the mantle wedge below Kamchatka, evidence from across-arc geochemical variation. Journal of Petrology, 42(8), 1567-1593. https://doi.org/10.1093/petrology/42.8.1567

Hart, S. R. (1984). A large-scale isotope anomaly in the Southern Hemisphere mantle. Nature, 309(5971), $753-757$. https://doi.org/10.1038/309753a0

Dmitriev V.D., Ezhov B.V. (1977). About question of genesis of Avacha bay. Questions of geography of Kamchatka. 7. p. 4547 (in Russian).

Dirksen O. V. (2009). Late Quaternary Areal Volcanism of Kamchatka. Doctoral dissertation, Sankt-Petersburg State University. p. 171 (in Russian). 
Dubik Yu.M., Ogorodov N.V. (1970). Volcanic cone in Avacha bay. Questions of geography of Kamchatka. 6. P. 171-172 (in Russian).

Duggen, S., Portnyagin, M., Baker, J., Ulfbeck, D., Hoernle, K., Garbe-Schönberg, D., Grassineau, N. (2007). Drastic shift in lava geochemistry in the volcanic-front to rear-arc region of the Southern Kamchatkan subduction zone: Evidence for the transition from slab surface dehydration to sediment melting. Geochimica et Cosmochimica Acta, 71(2), 452-480. https://doi.org/10.1016/j.gca.2006.09.018

Emelyanova T. A., Lelikov E. P. (2013). Volcanism as an indicator of a depth mechanism for the formation of the Seas of Japan and Okhotsk. Russian Journal of Pacific Geology, 7(2), 124-132. https://doi.org/10.1134/S1819714013020036

Favorskaya M.A., Volchanskaya I.K., Frich-har D.I., Baskina V.A., Dudykina A.S. (1965). Magmatism of south-east Kamchatka and their relantion with tectonic activation. Moscow. Nauka. P. 151 (in Russian).

Florensky I.V., Bazanova L.I. (1989). Volcanism during cenozoic time in South-East of Kamchatka (Beregovoy ridge). Volcanology and seismology. 6, 30-41 (in Russian).

Ishimaru S., Arai S., Ishida Y., Shirasaka M., Okrugin V. M. (2007). Melting and multi-stage metasomatism in the mantle wedge beneath a frontal arc inferred from highly depleted peridotite xenoliths from the Avacha volcano, southern Kamchatka. Journal of Petrology, 48(2), 395-433. https://doi.org/10.1093/petrology/eg1065

Ishimaru S., Arai, S. (2011). Peculiar Mg-Ca-Si metasomatism along a shear zone within the mantle wedge: inference from fine-grained xenoliths from Avacha volcano, Kamchatka. Contributions to Mineralogy and Petrology, 161(5), 703-720. DOI $10.1007 / \mathrm{s} 00410-010-0558-3$

Gazel, E., Carr, M. J., Hoernle, K., Feigenson, M. D., Szymanski, D., Hauff, F., \& Van Den Bogaard, P. (2009). GalapagosOIB signature in southern Central America: Mantle refertilization by arc-hot spot interaction. Geochemistry, Geophysics, Geosystems, 10(2). doi:10.1029/2008GC002246

Geological, geophysical atlas of the Kurile Kamchatka island arc (1987). VSEGEI. Leningrad. p. 36 (in Russian).

Geological map of Russian Federation (2000). Scale 1:200 000. Issue Sothern Kamchatka. Lists N-57-XXVII, N-57-XXXIII. Moscow, 302 (in Russian).

Geology of USSR (1967). XXXI. Kamchatka, Komandor and Kurile islands. Edite by G.M. Vlasov. Moscow. Nedra. P. 733 (in Russian)

Global volcanism program (GVP). https://volcano.si.edu. Date of ascess:01.04.2021

Grib E.N. (1985). The andesites of Mount Mishennaya. Questions of geography of Kamchatka.9. p. 130-133 (in Russian).

Grib E.N., Delemen' I.F., and Fedotov S.A., The Structure, Composition, and Origin of the Andesite Dome of Mount Mishennaya, Kamchatka, Vulkanol. Seismol., 1986, no. 6, pp. 29-44 (in Russian).

Gontovaya, L. I., Popruzhenko, S. V., Nizkous, I. V. (2010). Upper mantle structure in the ocean-continent transition zone: Kamchatka. Journal of Volcanology and Seismology, 4(4), 232-247. https://doi.org/10.1134/S0742046310040020

Nakamura K. (1977). Volcanoes as possible indicators of tectonic stress orientation principle and proposal. J. Volcanol. Geotherm. Res. Vol.2. P. 1-16. https://doi.org/10.1016/0377-0273(77)90012-9

Németh, K. (2010). Monogenetic volcanic fields: Origin, sedimentary record, and relationship with polygenetic volcanism. What is a Volcano?, 470, 43.

Hourigan, J. K.; Brandon, M. T.; Soloviev A. V.; Kirmasov A. B.; Garver J. I.; Stevenson, J.; and Reiners, P. W. (2009). Eocene arccontinent collision and crustal con- solidation in Kamchatka, Russian Far East. Am. J. Sci. 309:333-396. DOI: https://doi.org/10.2475/05.2009.01

Nurmukhamedov A. G., Sidorov M. D. (2019). Deep structure and geothermal potential along the regional profile set from Opala Mountain to Vakhil'River (Southern Kamchatka). In IOP Conference Series: Earth and Environmental Science, 249, 1, 012041. doi:10.1088/1755-1315/249/1/012041

Kimura J. I., Yoshida T. (2006). Contributions of slab fluid, mantle wedge and crust to the origin of Quaternary lavas in the NE Japan arc. Journal of Petrology, 47(11), 2185-2232. https://doi.org/10.1093/petrology/eg1041

Khanchuk A. I., Kemkin I. V., Kruk, N. N. (2016). The Sikhote-Alin orogenic belt, Russian South East: Terranes and the formation of continental lithosphere based on geological and isotopic data. Journal of Asian Earth Sciences, 120, 117-138. https://doi.org/10.1016/j.jseaes.2015.10.023

Konstantinovskaya E. (2011). Early Eocene arc-continent collision in Kamchatka, Russia: structural evolution and geodynamic model. In Arc-Continent Collision (pp. 247-277). https://doi.org/10.1007/978-3-540-88558-0_9

Kozhurin A. I., Ponomareva V. V., Pinegina T. K. (2008). Active faulting in the south of Central Kamchatka. Bulletin of Kamchatka Regional Association Educational-Scientific Center. Earth Sciences (2), 10-27 (in Russian).

Krasheninnikov, S. P., Bazanova, L. I., Ponomareva, V. V., Portnyagin, M. V. (2020). Detailed tephrochronology and composition of major Holocene eruptions from Avachinsky, Kozelsky, and Koryaksky volcanoes in Kamchatka. Journal of Volcanology and Geothermal Research, 107088. https://doi.org/10.1016/j.jvolgeores.2020.107088

Krohin E.M. (1954). About sone volcanic structures in valley of Malaya Bustraya, Levaya Topolovaya, Bolshaya Saranaya. Bulleten of volcanological station. 22. P. 39-43 (in Russian).

Maccaferri F., Acocella V., Rivalta E. (2015). How the differential load induced by normal fault scarps controls the distribution of monogenic volcanism. Geophysical Research Letters, 42(18), 7507-7512. https://doi.org/10.1002/2015GL065638

Masurenkov Y. P., Egorova I. A., Puzankov M. Y. (1991). Avachinsky Volcano: Kamchatka active volcanoes. Active Volcanoes of Kamchatka, 2, 246-273 (in Russian).

Martí J., López C., Bartolini S., Becerril L., Geyer, A. (2016). Stress controls of monogenetic volcanism: a review. Frontiers in Earth Science, 4, 106. http://dx.doi.org/10.3389/feart.2016.00106

Mitichkin, M. A., Perepelov, A. B., Dril, S. I., Chuvashova, L. A., Smirnova, E. V. (1998). Rare Earth Elements and the Geochemical Typification of Intrusive Rocks from the Malka-Petropavlovsk Transverse Fault Zone, Kamchatka. In Doklady earth sciences . 362, 7, pp. 974-977 (in Russian). 
Moroz, Y. F., and Gontovaya, L. I. (2003). Deep structure of Avachinsky-Koryaksky group of volcanoes. Volcanology and Seismology, 4. P.3-10 (in Russian).

Moroz Y. F., Gontovaya L. I. (2018). Deep structure of South Kamchatka according to geophysical data. Geodynamics \& Tectonophysics, 9(4), 1147-1161. https://doi.org/10.5800/GT-2018-9-4-0387

Miyashiro, A. (1974). Volcanic rock series in island arcs and active continental margins. American journal of science, 274(4), 321-355. https://doi.org/10.2475/ajs.274.4.321

Lander A. V., Shapiro M. N. (2007). The origin of the modern Kamchatka subduction zone. Washington DC American Geophysical Union Geophysical Monograph Series, 172, 57-64. 10.1029/172GM05

Larionova Y. O., Samsonov A. V., Shatagin K. N. (2007). Sources of Archean sanukitoids (high-Mg subalkaline granitoids) in the Karelian Craton: Sm-Nd and Rb-Sr isotopic-geochemical evidence. Petrology, 15(6), 530-550.

https://doi.org/10.1134/S0869591107060021

Leonov V. L., Rogozin A. N. (2007). Karymshina, a giant supervolcano caldera in Kamchatka: Boundaries, structure, volume of pyroclastics. Journal of Volcanology and Seismology, 1(5), 296-309. https://doi.org/10.1134/S0742046307050028

Loginov V.A., Gontovaya L.I. (2020). Structure of the lithosphere in Avacha-Koryak group of volcano based on geohysical data (Kamchatka). Annual conference to volcanological day «Volcanism and related process». P. 107-109 (in Russian).

Pardo N., Macias J. L., Giordano G., Cianfarra P., Avellán D. R., Bellatreccia, F. (2009). The 1245 yr BP Asososca maar eruption: The youngest event along the Nejapa-Miraflores volcanic fault, Western Managua, Nicaragua. Journal of Volcanology and Geothermal Research, 184(3-4), 292-312. https://doi.org/10.1016/j.jvolgeores.2009.04.006

Pearce J. A. (2008). Geochemical fingerprinting of oceanic basalts with applications to ophiolite classification and the search for Archean oceanic crust. Lithos, 100(1-4), 14-48. https://doi.org/10.1016/j.lithos.2007.06.016

Pinegina, T. K., Bazanova, L. I., Zelenin, E. A., Bourgeois, J., Kozhurin, A. I., Medvedev, I. P., \& Vydrin, D. S. (2018). Holocene Tsunamis in Avachinsky Bay, Kamchatka, Russia. Pure and Applied Geophysics, 175(4), $1485-1506$. https://doi.org/10.1007/s00024-018-1830-0

Ponomareva V. V., Melekestsev I. V., Dirksen O. V. (2006). Sector collapses and large landslides on Late PleistoceneHolocene volcanoes in Kamchatka, Russia. Journal of Volcanology and Geothermal Research, 158(1-2), 117-138. https://doi.org/10.1016/j.jvolgeores.2006.04.016

Popruzhenko S.V., Zubin M.I. (1997). Tectonics and some features of seismicity of the shelf zone of the Avacha Bay and adjacent areas. Volcanology and Seismology. 2. P. 74-81 (in Russian).

Putirka, K. D. (2008). Thermometers and barometers for volcanic systems. Reviews in mineralogy and geochemistry, 69(1), 61-120. https://doi.org/10.2138/rmg.2008.69.3

Rehkämper, M., Halliday, A.M., 1998. Accuracy and long-term reproducibility of lead isotopic measurements by MC-ICP-MS using an external method for correction of mass discrimination. Int. J. Mass Spec. 181, 123-133. https://doi.org/10.1016/S13873806(98)14170-2.

Seliverstov N. I. (2009). Geodynamics of the Junction Zone of the Kuril-Kamchatka and Aleutian Island Arc. PetropavlovskKamchatsky: KamGU, p. 191 (in Russian).

Shatser A.E. (1987). Cainozoic development of Kamchatka - formation and destruction unstable orogenetic uplifts. In: Essays of tectonic development of Kamchatka (Belousov V.V. edt). Nauka. M. p. 109-164 (in Russian).

Sharapov, V. N., Kuznetsov, G. V., Logachev, V. P., Cherepanova, V. K., Cherepanov, A. N. (2017). Modeling the dynamics of sublimation of fractured rocks in the lithospheric mantle wedge beneath volcanoes of the Avacha group (Kamchatka). Geochemistry International, 55(3), 231-250. https://doi.org/10.1134/S0016702917030065

Sharapov, V. N., Tomilenko, A. A., Kuznetsov, G. V., Perepechko, Y. V., Sorokin, K. E., Mikheeva, A. V., Semenov, Y. I. (2020). Mechanisms of Partial Melting of Metasomatized Mantle Ultramafic Rocks beneath Avacha Volcano, Kamchatka, and the Growth of Minerals from a Gas Phase in Fractures. Petrology, 28(6), 569-590. https://doi.org/10.1134/S0869591120050069

Sheimovich V.S., Sidorov M.D. 2000. Structure of the basement under the southest Kamchatka volcanic belt. Volcanology and seismology.5. p. 28-35 (in Russian).

Sheimovich, V.S., Patoka, M.G. 2000. Geological setting of zones with active cenozoic volcanism. Moscow: Geos, 208 (in Russian).

Sheimovich V.A., Puzankov Yu. M., Puzankov M.Yu., Golovin D.I., Bobrov V.A., Moskaleva S.V. (2005). Manifestations of alkaline magmatism in the Avacha bay area. Volcanology and seismilogy. 36.6. p. 36-46 (in Russian).

Sheimovich V. S., Golovin D. I., Gertsev D. O. (2007). The andesite extrusion of Mount Mishennaya, Kamchatka, and its age. Journal of Volcanology and Seismology, 1(4), 248-253. https://doi.org/10.1134/S0742046307040033

Svyatlovsky A.E. (1956). Yuzhno-Bustrinsky range. Works of volcanology laboratory. 12. p. 110-190 (in Russina).

Sugrobov V.M., Yanovsky F.A. (1991). Geothermal field of Kamchatka., heat Losses by volcanoes and hydroterms. In: Active volcanoes of Kamchatka. Edt: Fedotov S.A., Masurenkov Yu.P.1. 67-74.

Syracuse E. M., Abers G. A. (2006). Global compilation of variations in slab depth beneath arc volcanoes and implications. Geochemistry, Geophysics, Geosystems, 7(5). https://doi.org/10.1029/2005GC001045

Sun S. S., McDonough, W. F. (1989). Chemical and isotopic systematics of oceanic basalts: implications for mantle composition and processes. Geological Society, London, Special Publications, 42(1), 313-345.

https://doi.org/10.1144/GSL.SP.1989.042.01.19

Tsukanov N.V., Palechek T.N., Soloviev A.V., Savelyev D.P. (2014). Tectono-stratigraphic complexes of the southern segment of the Kronotsky paleoarc (East Kamchatka): their structure, age, and composition. Pacific Geology. 6. $33.3-17$ (in Russian).

Takarada, S. (2017). The volcanic hazards assessment support system for the online hazard assessment and risk mitigation of quaternary volcanoes in the world. Frontiers in Earth Science, 5, 102.

https://doi.org/10.3389/feart.2017.00102 
3 Federal State statistic Service. https://eng.gks.ru. Date of assecc: 26 October 2020.

4 Holocene volcanism of Kamchatka. http://geoportal.kscnet.ru/volcanoes/geoservices/hvolc. Date of assecc: 21 October 2020.

5 Seismological data information system KBGS RAS. http://sdis.emsd.ru/info/earthquakes/catalogue.php. Date of assecc: 1

5 November 2020 


\section{Figures}

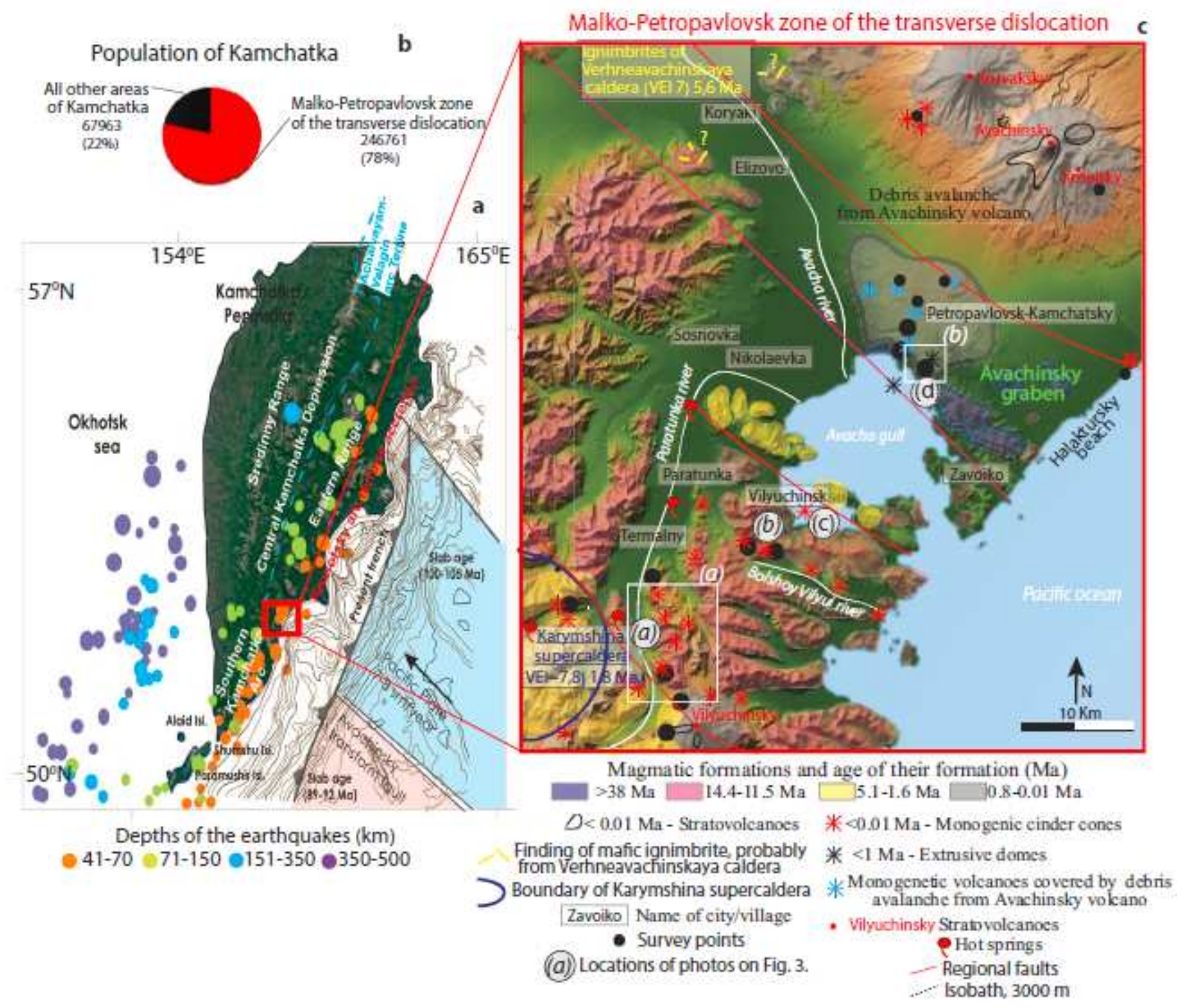

Figure 1

The present-day geodynamic setting of the Kamchatka Peninsula and MPZ; a Schematic map of the Kamchatka with main volcanic belts. The position of Kronotsky Arc terrane accretion is shown according to Lander and Shapiro (2007). The position of Achaivayam-Valagin arc terrain is demonstrated according to Cherkovich, Sukhov (2005). Isobaths in the continental slope of Kamchatka is shown according to Seliverstov (2009). The location of the Avachinsly transform fault is illustrated by Andreev (1993). Seismological data information system collected by KBGS RAS (2020); Chebrov et al., 2013; Chebrova et al., 2020. Ages of slabs presented by Syracuse, Abers (2006); b Percentage of the local population living in MPZ and all other parts of Kamchatka based on Federal's statistic calculations of Federal..., 2020. Data was calculated on the report of 2019; c Geological formations of MPZD are based on Geological map (2000), Krohin (1954), Dirksen (2009). The boundary of Karymshina caldera and distribution of ignimbrites of Verkhnaevachinskaya caldera are illustrated using Bergal-Kuvikas et al., 2019; Leonov and Rogozin, 2007. Locations of cinder cone of Khlebalkina island and extrusive dome in Avacha bay are 
shown using Dmitriev and Ezhov (1977). The positions of the regional faults are according to Geological map... (2002). Hot springs locations are from Chudaev et al., 2016. White rectangles show the area of detailed satellite images on Fig. 2. Note: The designations employed and the presentation of the material on this map do not imply the expression of any opinion whatsoever on the part of Research Square concerning the legal status of any country, territory, city or area or of its authorities, or concerning the delimitation of its frontiers or boundaries. This map has been provided by the authors.
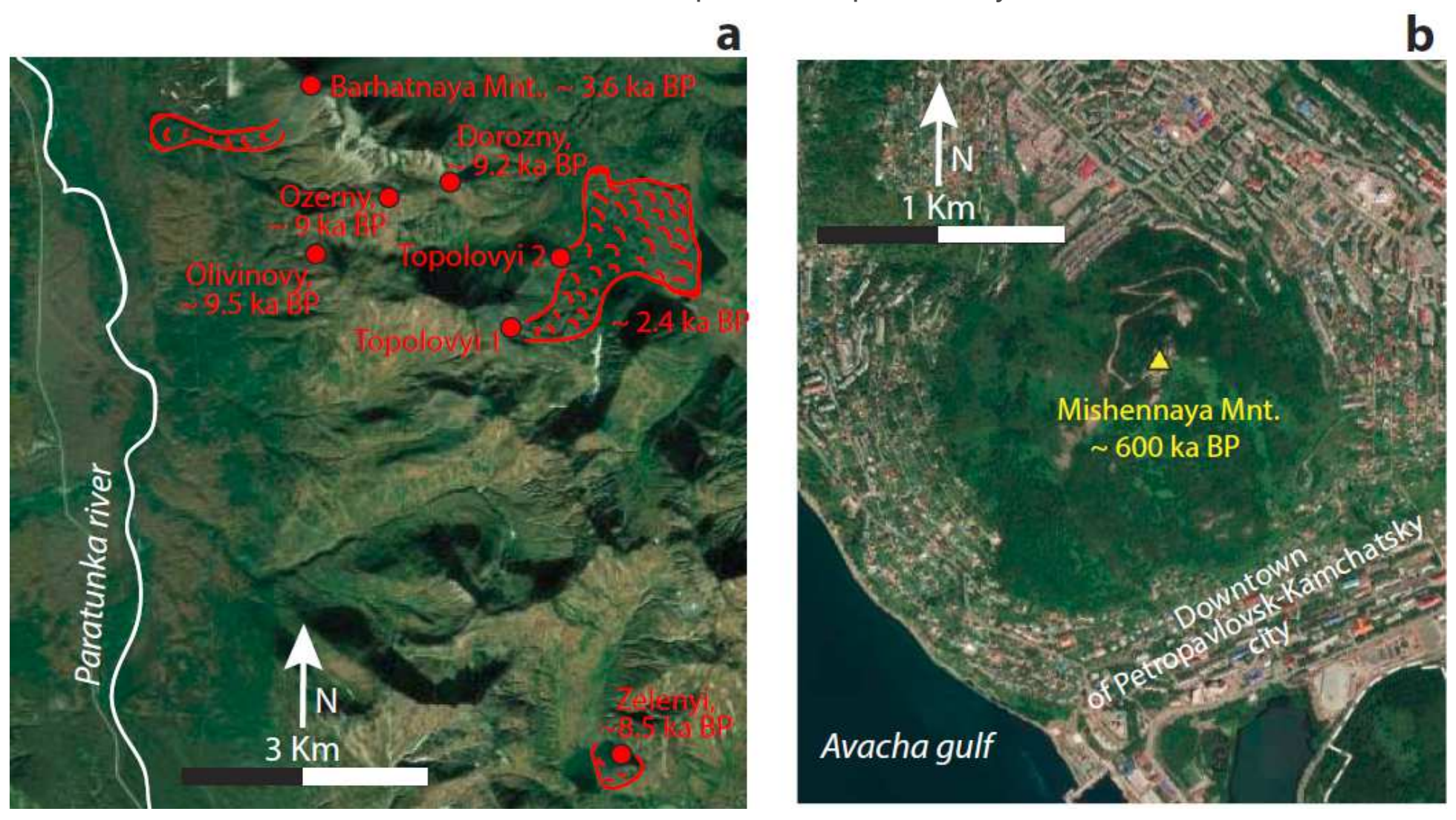

Figure 2

Satellite photos of long living rupture zone with various aged a monogenetic cinder cones and $b$ extrusive dome. Location of cinder cones, lava flows and aged shown according to Dirksen (2009), Geological map.., 2000. Note: The designations employed and the presentation of the material on this map do not imply the expression of any opinion whatsoever on the part of Research Square concerning the legal status of any country, territory, city or area or of its authorities, or concerning the delimitation of its frontiers or boundaries. This map has been provided by the authors. 


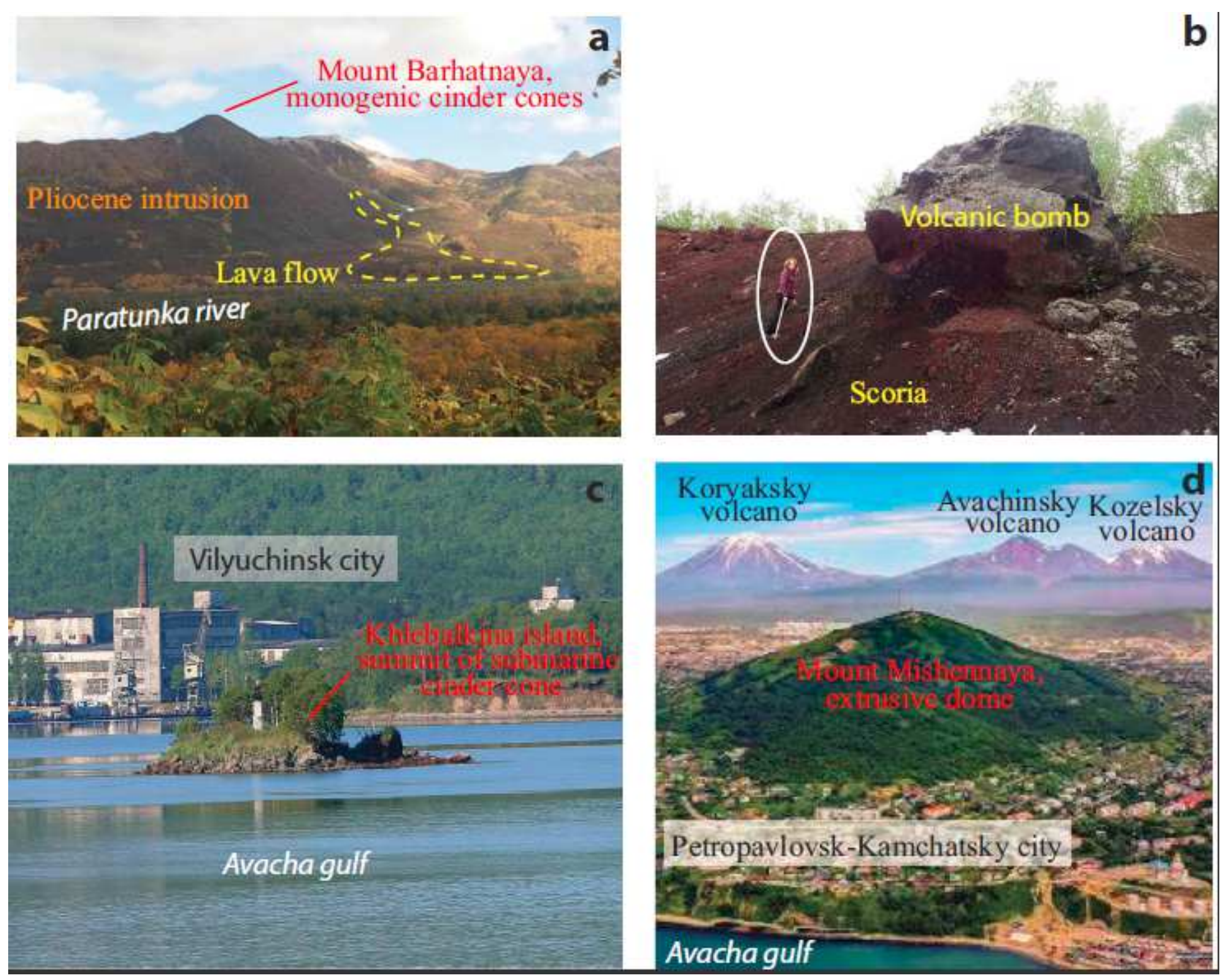

\section{Figure 3}

Photos of monogenic volcanism are in MPZ. Locations of illustrations are on Fig. $1 \mathrm{~b}$; a cinder cone Barhatnaya in the valley of Paratunka river; b cinder cone near Vilyuchinsk city; c Khlebalkina isl. is a summit of cinder cone of Avacha bay, photo from press-toff.livejournal.com; (d) extrusive dome Mishennaya in centre of Petropavlovsk-Kamchatsky city, photo from www.instazu.com. Note: The designations employed and the presentation of the material on this map do not imply the expression of any opinion whatsoever on the part of Research Square concerning the legal status of any country, territory, city or area or of its authorities, or concerning the delimitation of its frontiers or boundaries. This map has been provided by the authors. 
Volcanic front

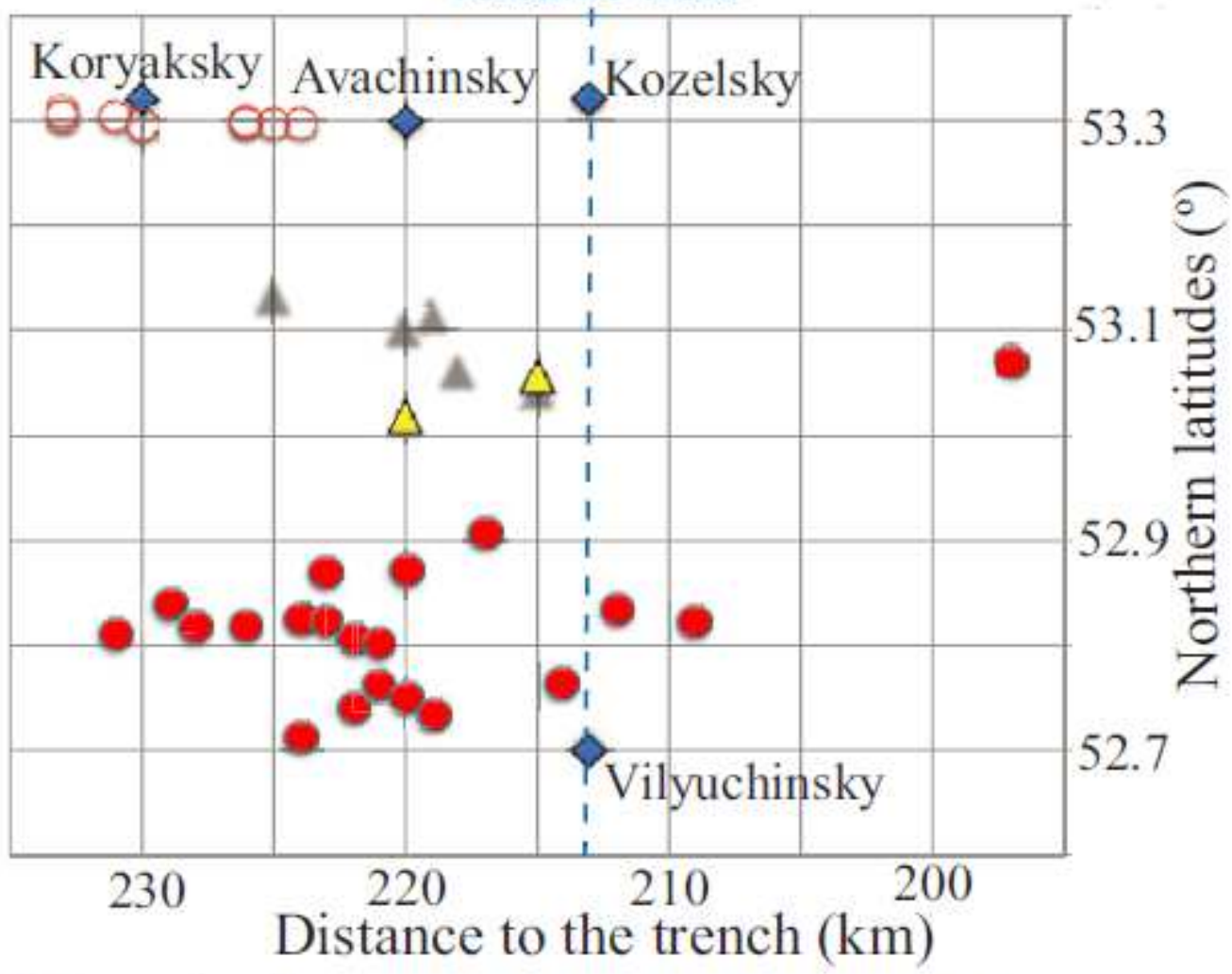

$\triangle$ Extrusive domes

- Cinder cones

Monogenetic volcanoes

covered by debris avalanche

from Avachinsky volcano

\section{Figure 4}

The geodynamic setting of the Holocene volcanoes is in MPZ in correlation to the distance to the trench. According to the Geological map (2000), positions of the cones are shown locations of the submarine cones in Avacha bay by Dmitriev and Ezhov (1977). The blue dotted line is the hypothetical line of volcanic front. 


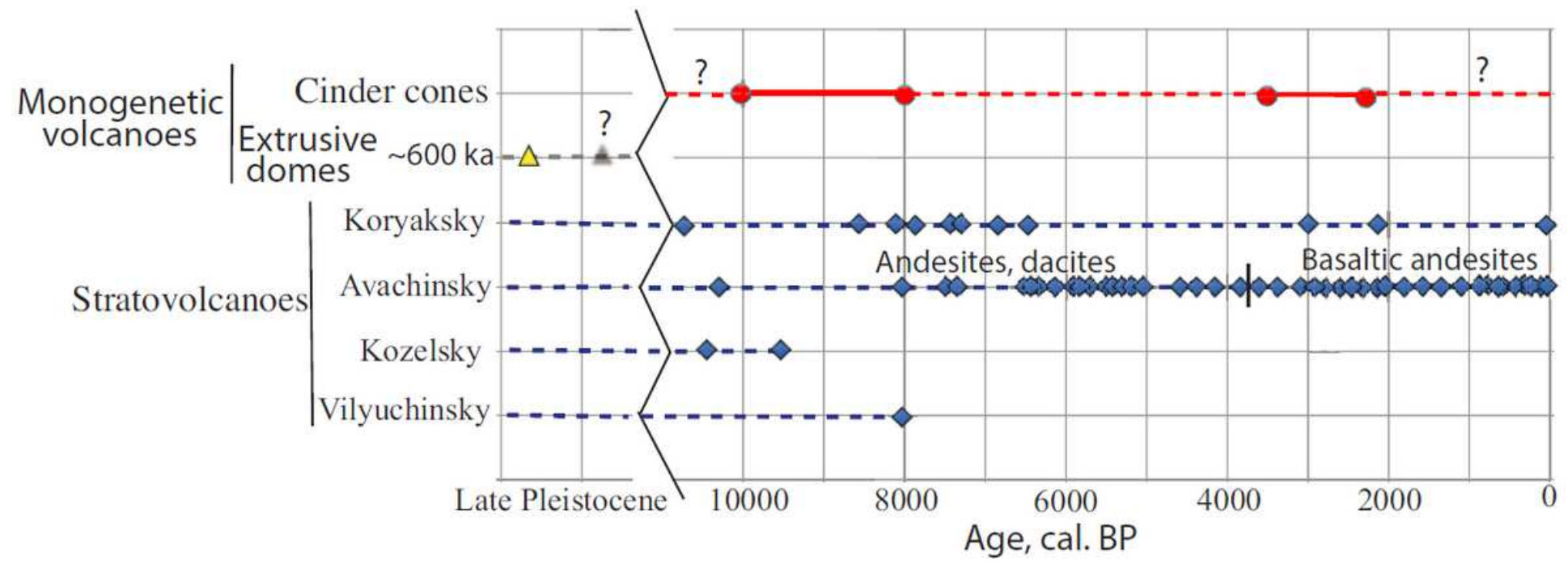

\section{Figure 5}

Temporal variations of monogenetic volcanoes and stratovolcanoes in MPZ are based on data from Aprelkov, Borzynova, 1963; Dirksen, 2009; Geological map..., 2000; Global..., 2021; Krasheninnikov et al., 2020; Masurenkov et al., 1991; Sheimovich et al., 2007, Holocene..., 2020. Symbols show absolute dating of eruptions. The dotted line is the time of activations. Symbols are the same as on Fig. 3. 

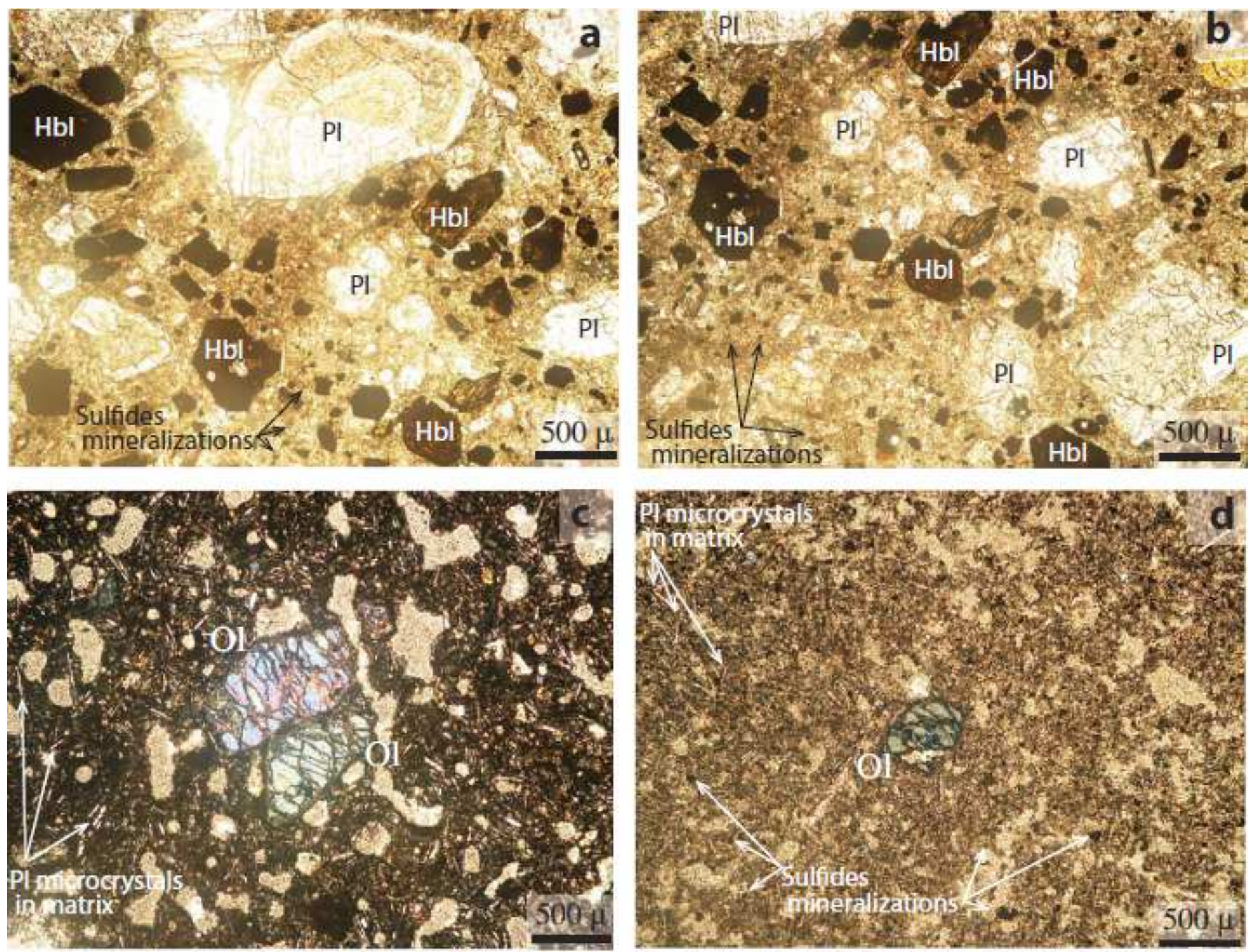

\section{Figure 6}

Thin sections of a, b Hbl andesites of extrusive dome Mishennaya Mount and c, d Olbearing basaltic andesites of the monogenetic cones. 
a
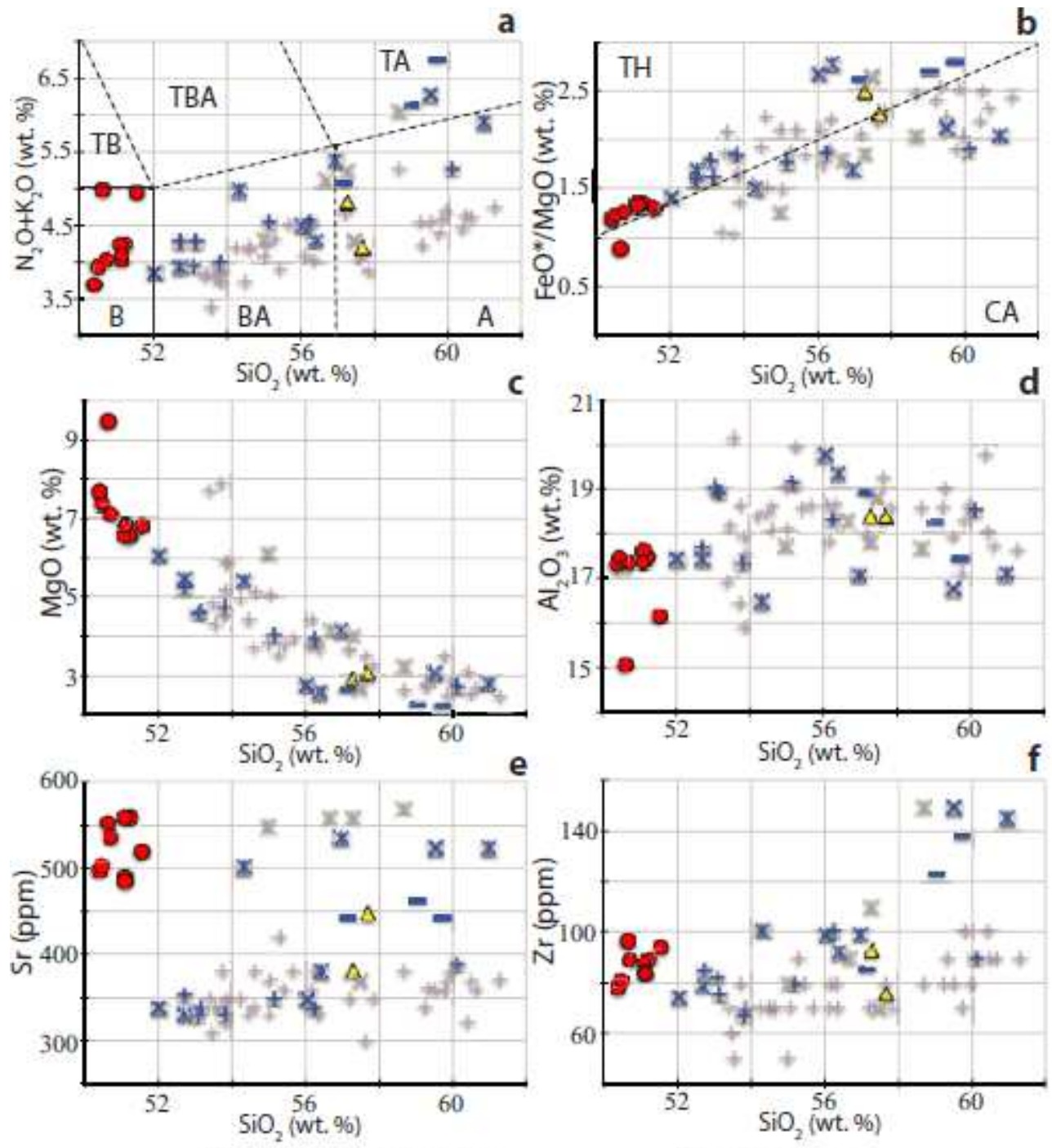

Monogenetic volcanoes

$\Delta$ Extrusive dome

Stratovolcanoes

-Cinder cones

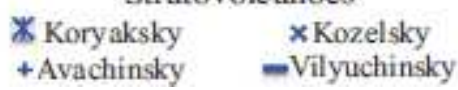

Figure 7

Silica variations diagrams with significant oxides and trace elements. Abbreviations in a TAS diagram indicate standard fields of rock compositions are: basalts (B), basaltic andesites (BA), andesites (A), trachybasalts (TB), trachybasaltic andesites (TBA), trachyandesites (TA). Discrimination lines on tholeiitic (TH) and calc-alkaline series on diagram b are according to Miashiro (1974). Grey symbols are tephra compositions from Koryaksky, Avachinsky, Kozelsky volcanoes (Krasheninnikov et al., 2020). 

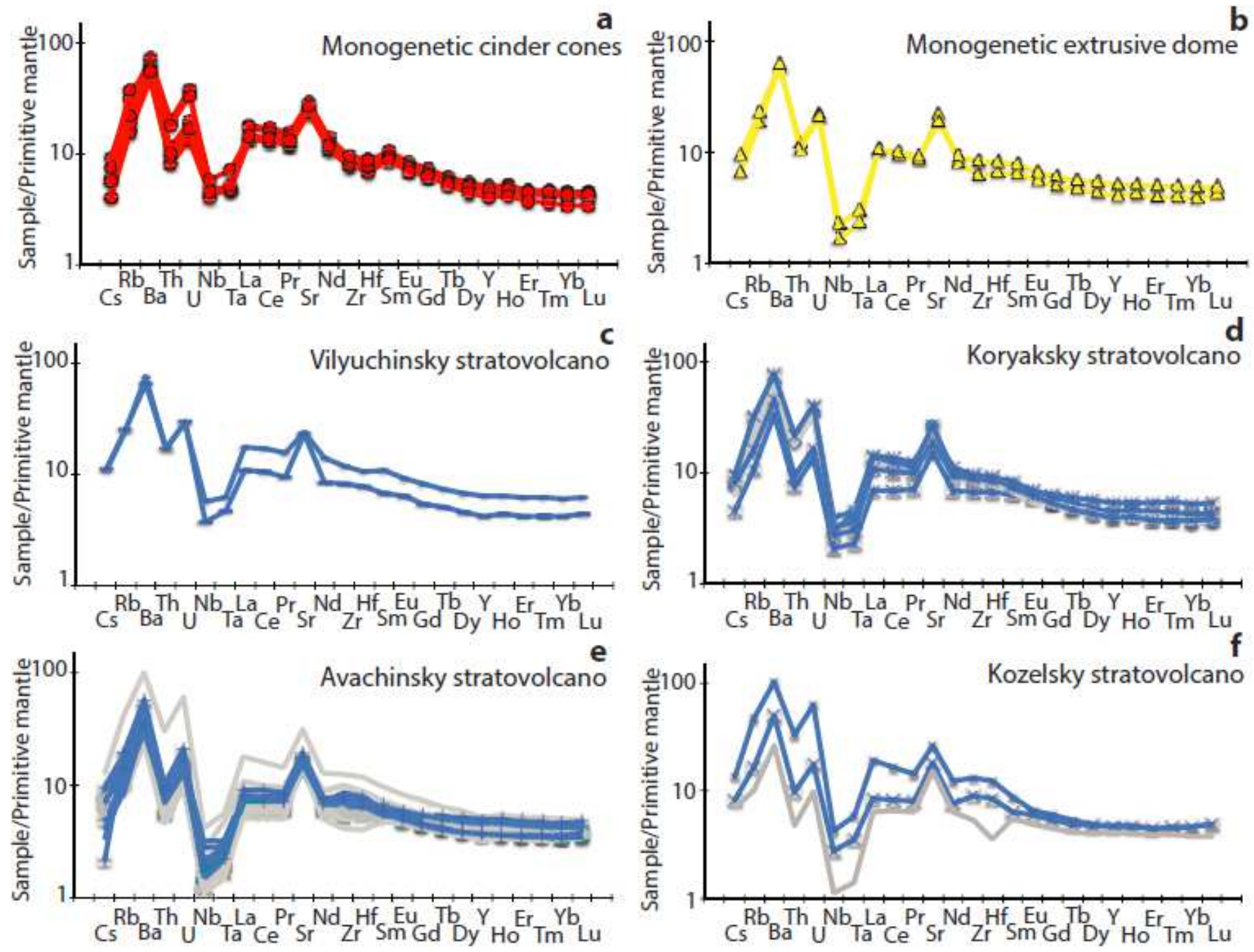

\section{Figure 8}

Primitive mantle-normalized multi-element concentrations diagrams. Trace element concentrations of the primitive mantle are taken from Sun, McDonought (1989). Grey symbols are tephra compositions from Koryaksky, Avachinsky, Kozelsky volcanoes (Krasheninnikov et al., 2020). 

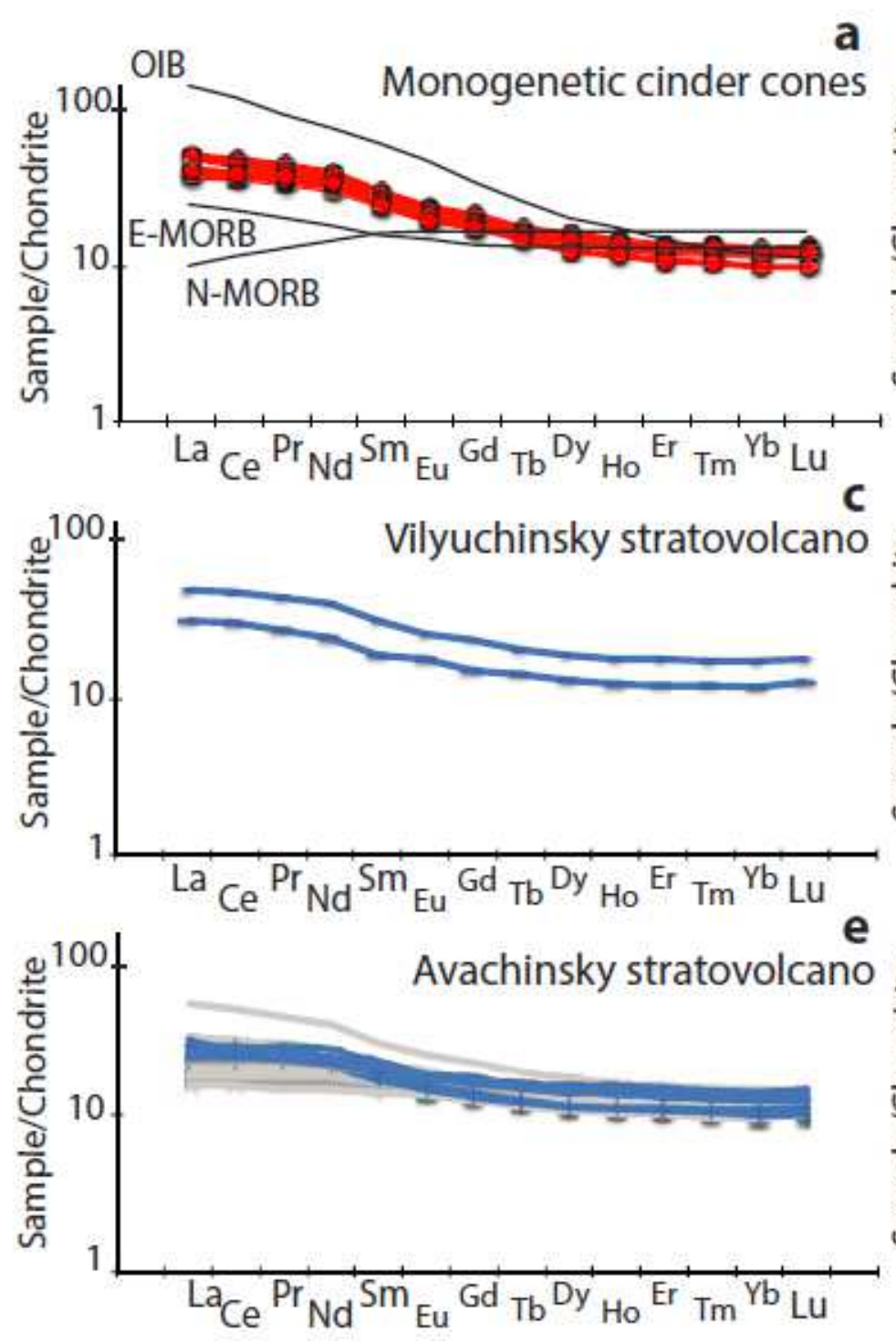

Monogenetic extrusive dome
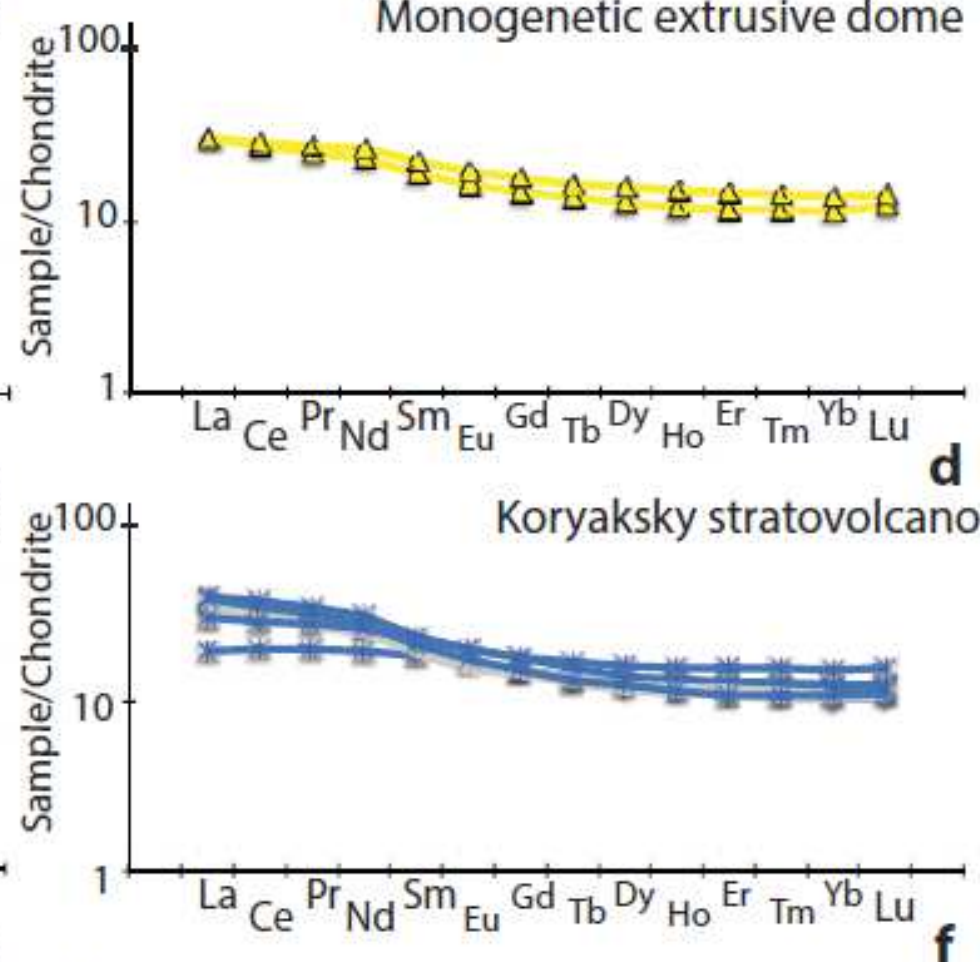

Kozelsky stratovolcano

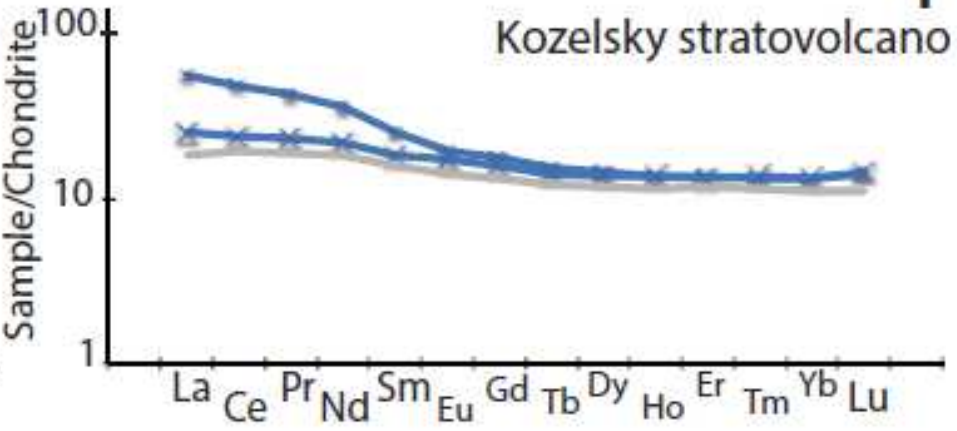

Figure 9

Chondrite-normalized trace elements diagrams. E-MORB, N-MORB, OIB are according to Sun, McDonought (1989). Grey symbols are tephra compositions from Koryaksky, Avachinsky, Kozelsky volcanoes (Krasheninnikov et al., 2020). 


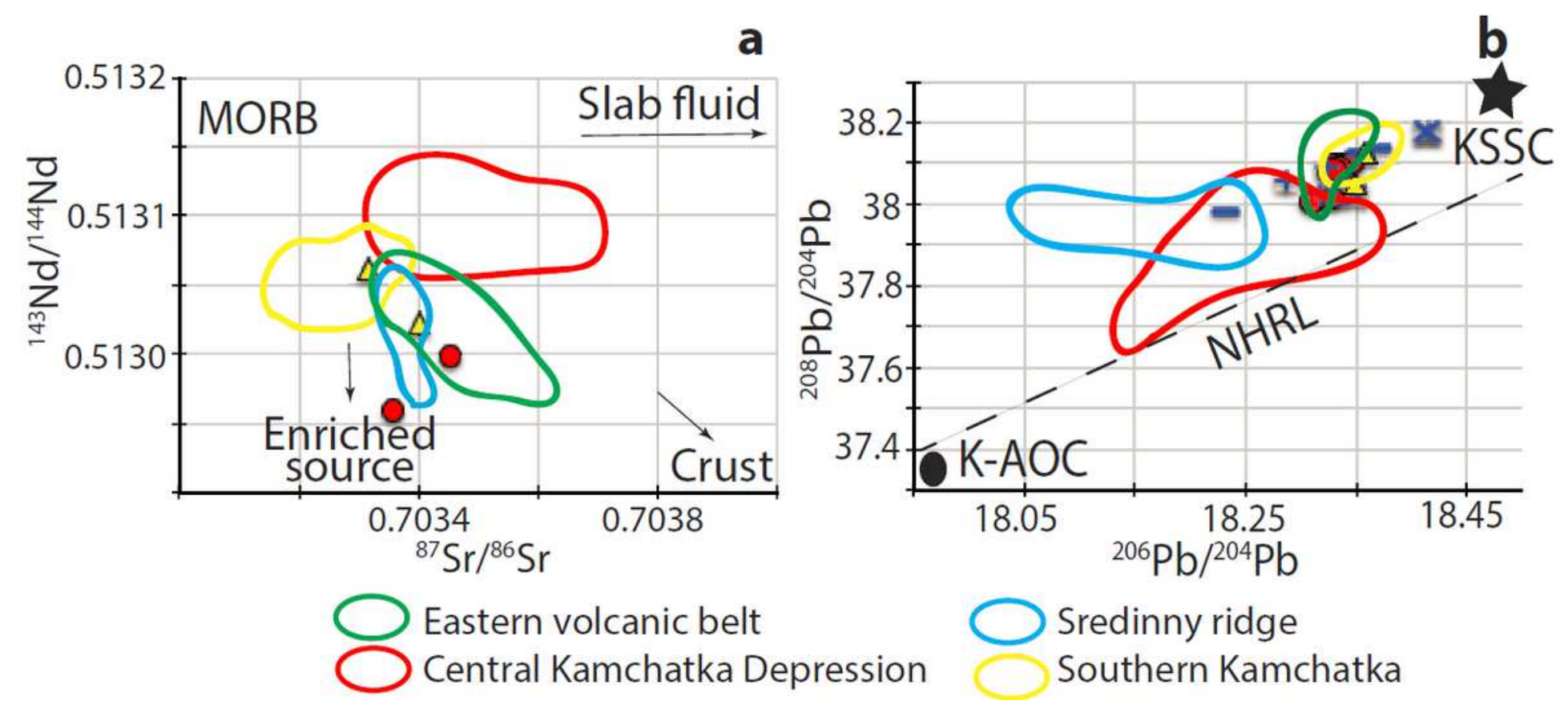

Figure 10

a Sr-Nd and b Pb isotope diagrams b show monogenetic and polygenetic volcanoes. Symbols are the same as in Fig. 7. The dashed line is the Northern Hemisphere Reference Line (NHRL) (Hart, 1984). Star is Kamchatka subduction sediment column (KSSC). Black circle is Kamchatkan altered oceanic crust (KAOC) according to Duggen et al., 2007. Isotope variations of the Eastern volcanic belt, Sredinny ridge, Central Kamchatkan Depression are based on Churikova et al., 2001. Southern Kamchatka isotope variations are preset by Duggen et al., 2007. 


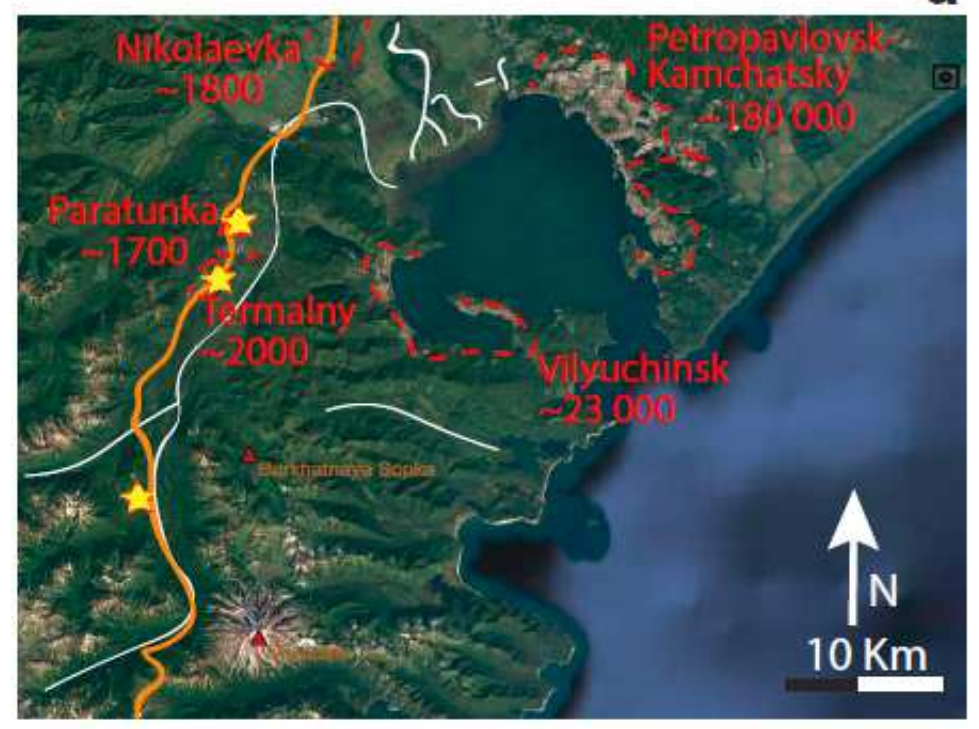

..... Vilyuchinsk Boundary and name of the city $\sim 23000$

Road with residences numbers s? Resort

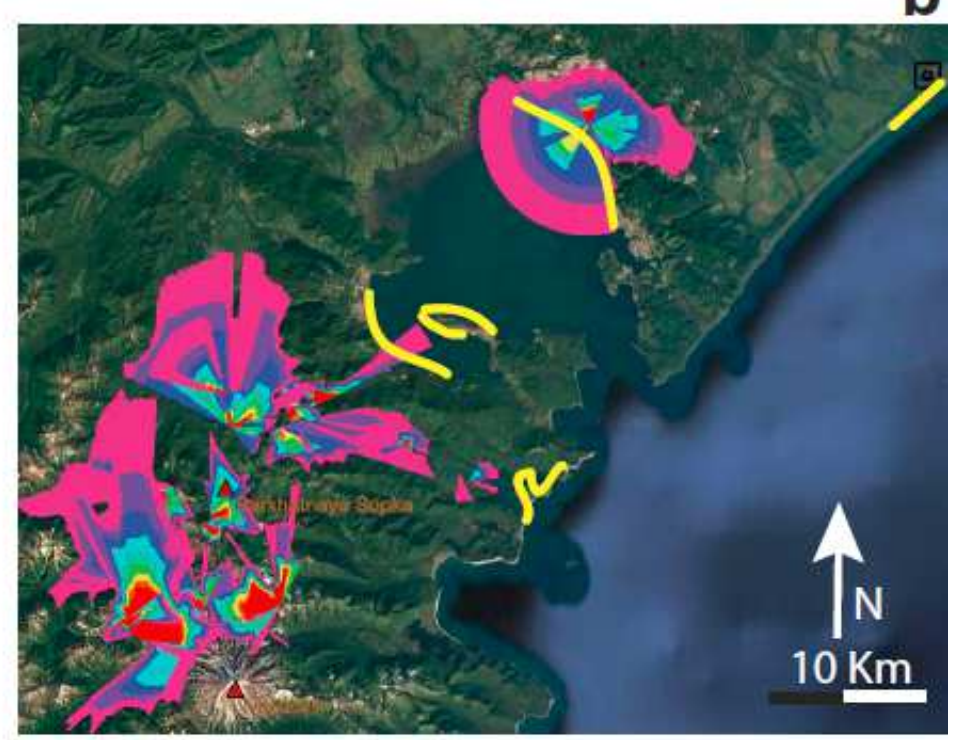

The volcanic hazards assessment suport system (Energy cone modeling) $\mathrm{H} / \mathrm{L}>0.21 \mathrm{H} / \mathrm{L}=0.21-0.19$ $\mathrm{H} / \mathrm{L}=0.19-0.17-\mathrm{H} / \mathrm{L}=0.17-0.15$ $\mathrm{H} / \mathrm{L}=0.15-0.13-\mathrm{H} / \mathrm{L}=0.13-0.11$ $\square \mathrm{H} / \mathrm{L}=0.11-0.09 \square \mathrm{H} / \mathrm{L}=0.09-0.07$ $\mathrm{H} / \mathrm{L}=0.07-0.05$

Potential hazards from magma-water interaction

\section{Figure 11}

Modelling of hazards from monogenetic volcanoes.: a infrastructures, main cities with human density are shown; $b$ An energy-cone simulation result of monogenetic volcanism based on volcanic hazards assessment support system (Takarada, 2017). $\mathrm{H} / \mathrm{L}$ is a ratio of relative height $(\mathrm{H})$ and lateral travel distance of the volcanic gravity flow (L). More details for modelling parameters are in the text and Takarada (2017). Note: The designations employed and the presentation of the material on this map do not imply the expression of any opinion whatsoever on the part of Research Square concerning the legal status of any country, territory, city or area or of its authorities, or concerning the delimitation of its frontiers or boundaries. This map has been provided by the authors. 

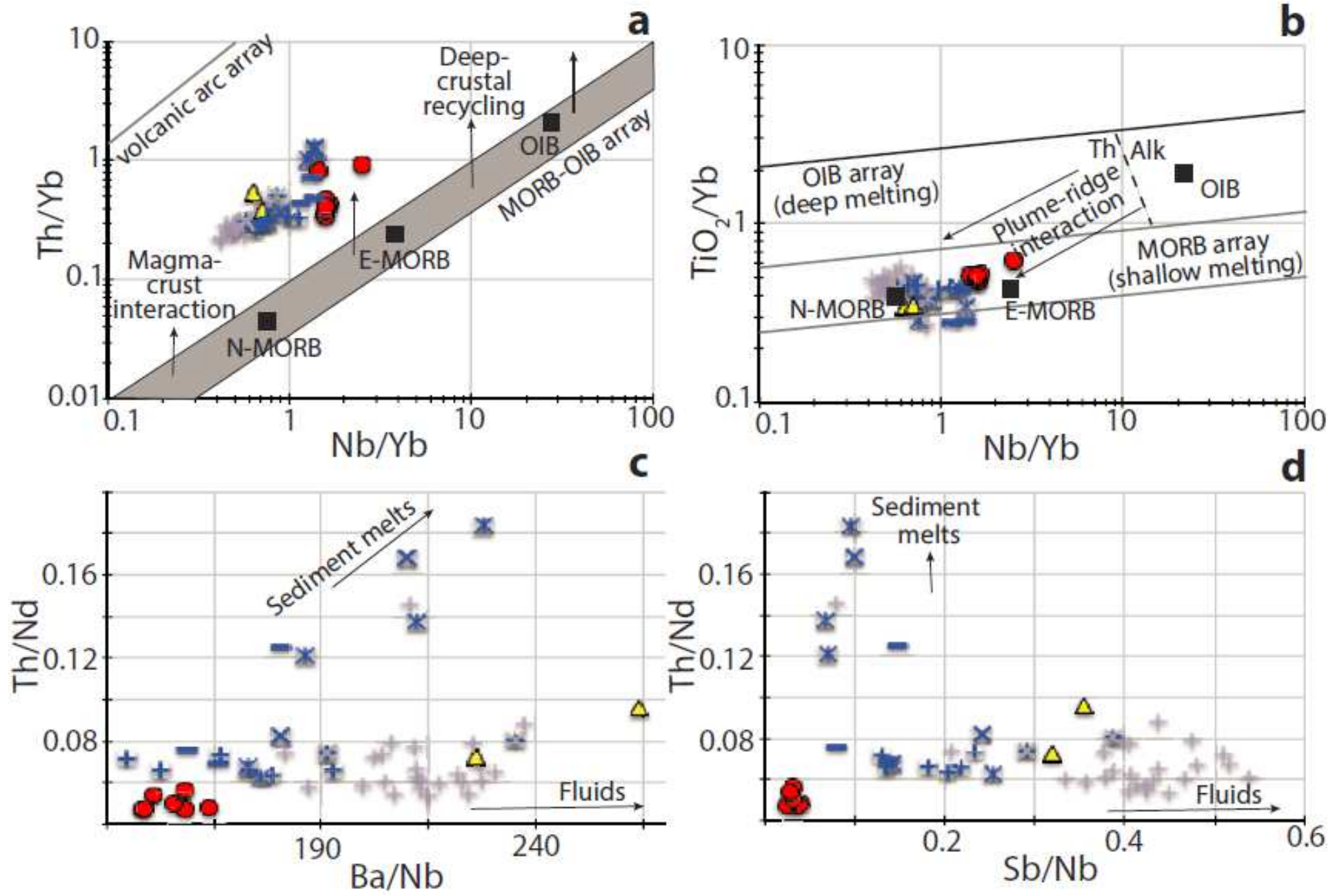

Figure 12

Ratios of trace element variations. Discrimination lines on a-b patterns are according to Pearce (2008). Symbols are the same as on Fig. 7.

Decompression

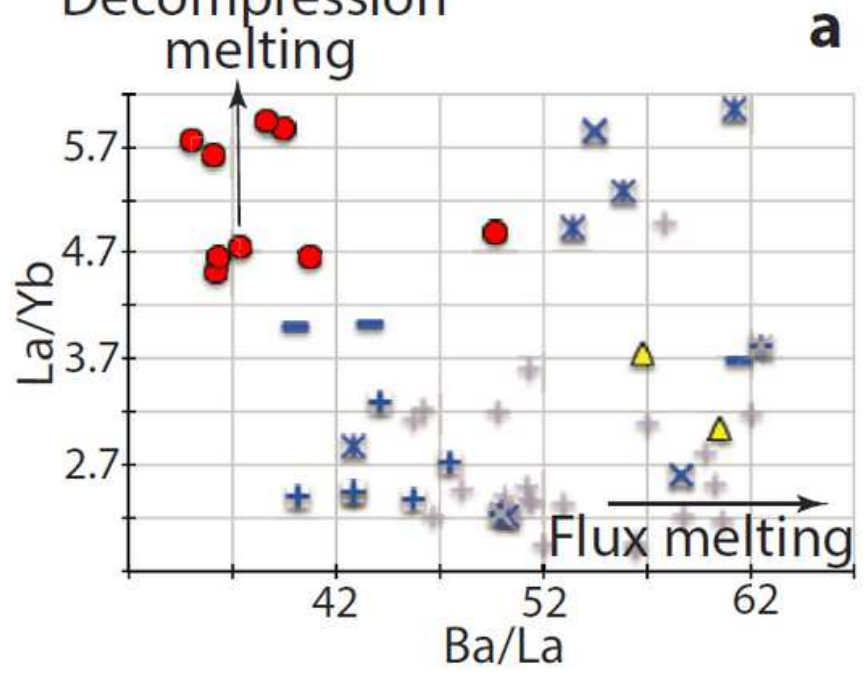

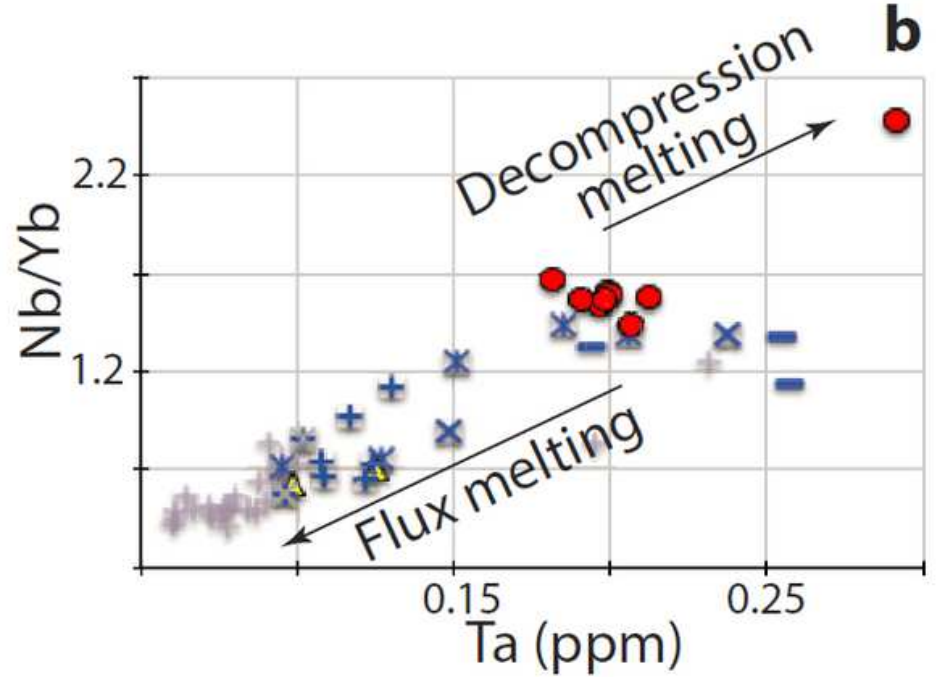

Figure 13 
a The $\mathrm{Ba} / \mathrm{La}$ versus $\mathrm{La} / \mathrm{Yb}$ and $\mathrm{b} \mathrm{Nb} / \mathrm{Yb}$ versus Ta diagrams serve to identify the main melting process in the mantle wedge.
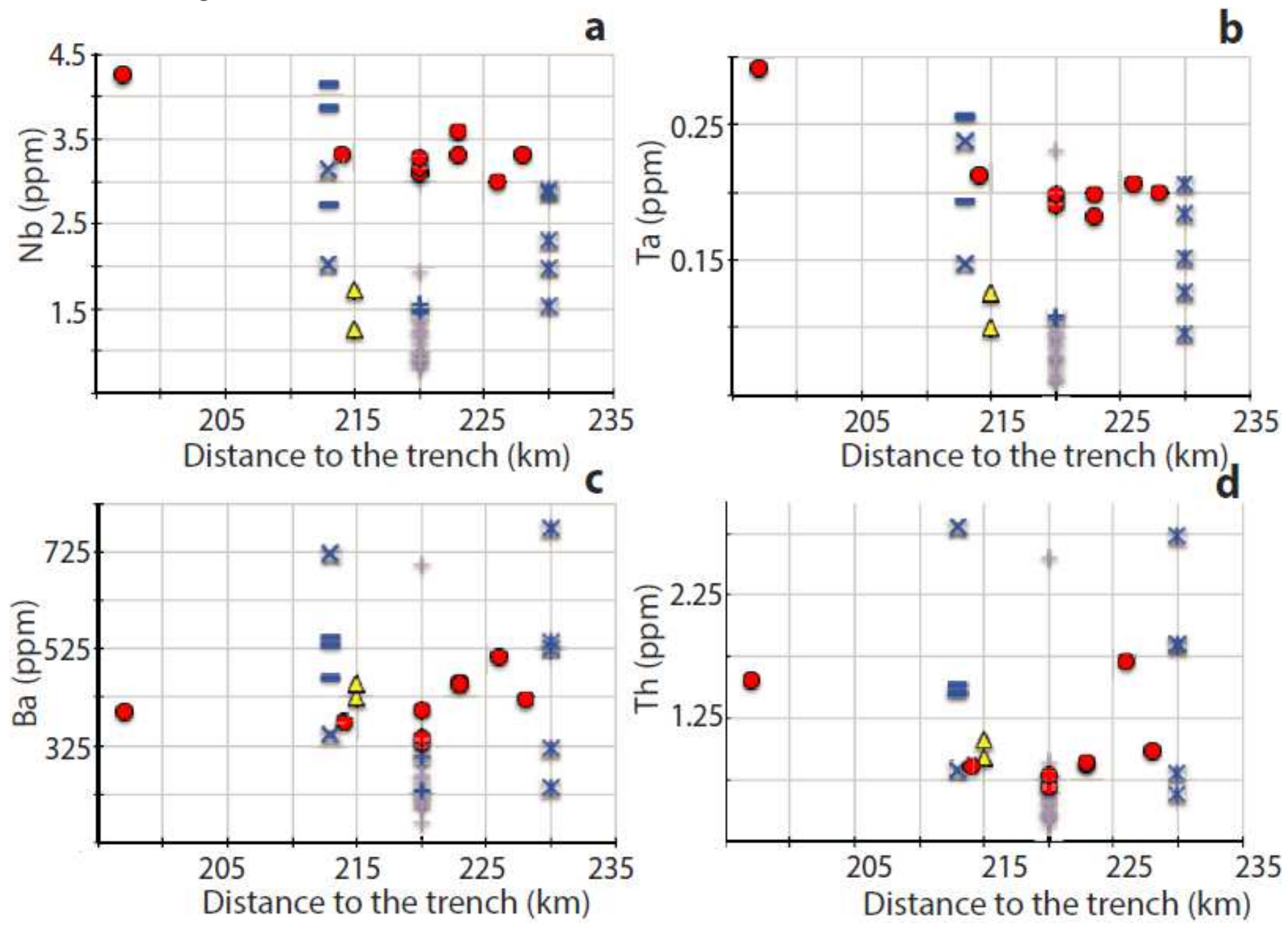

Figure 14

$a, b$ Variations of fluid-immobile and c, d fluid-mobile elements versus distance to the trench. Symbols as in Fig. 7. 


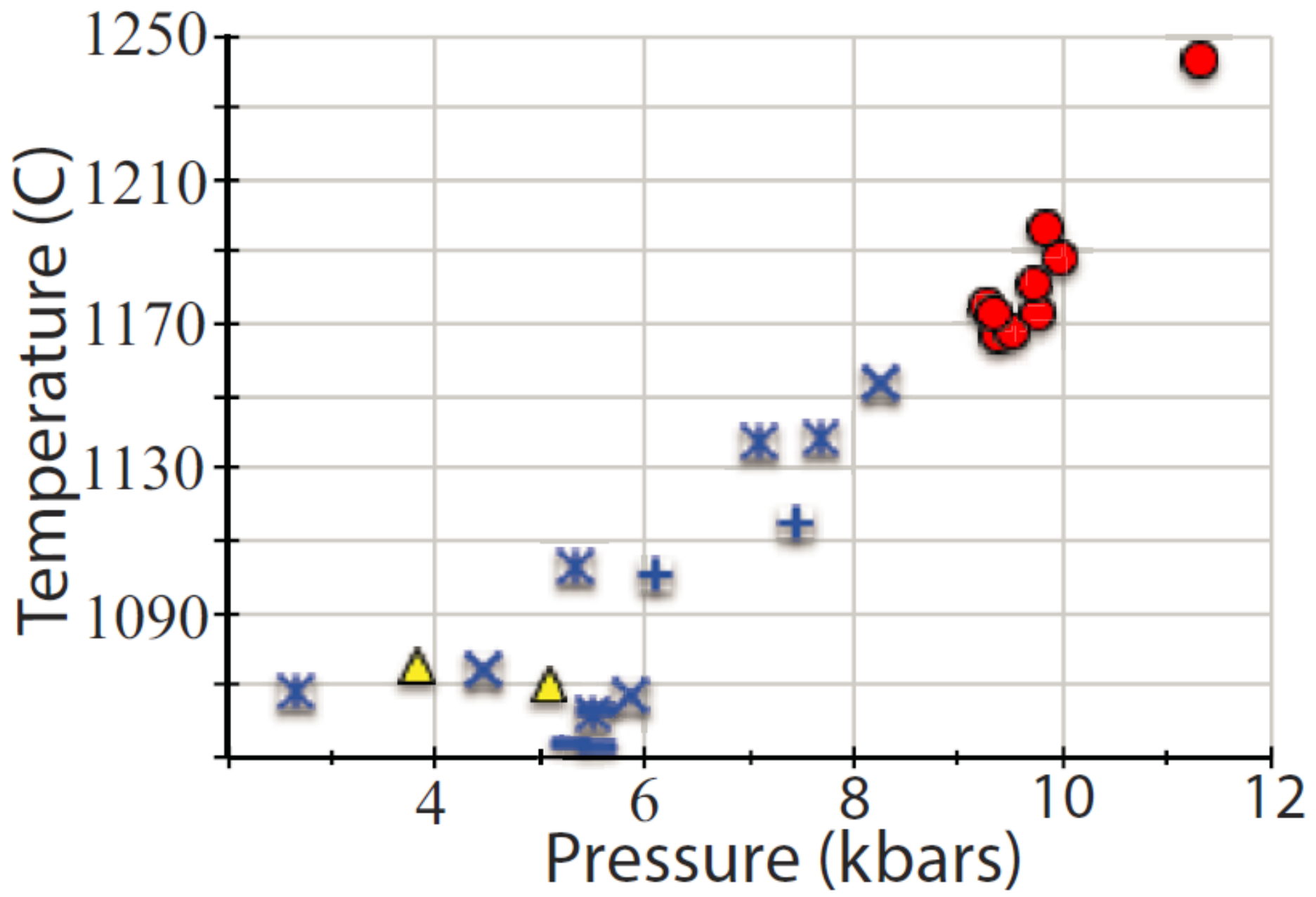

Figure 15

Pressure and temperature conditions for magma crystallization. Calculations are based on a glass thermometer by Helts, Thoernber (1987) and glass barometer by Putirka (2008). Symbols are the same as on Fig. 6. 


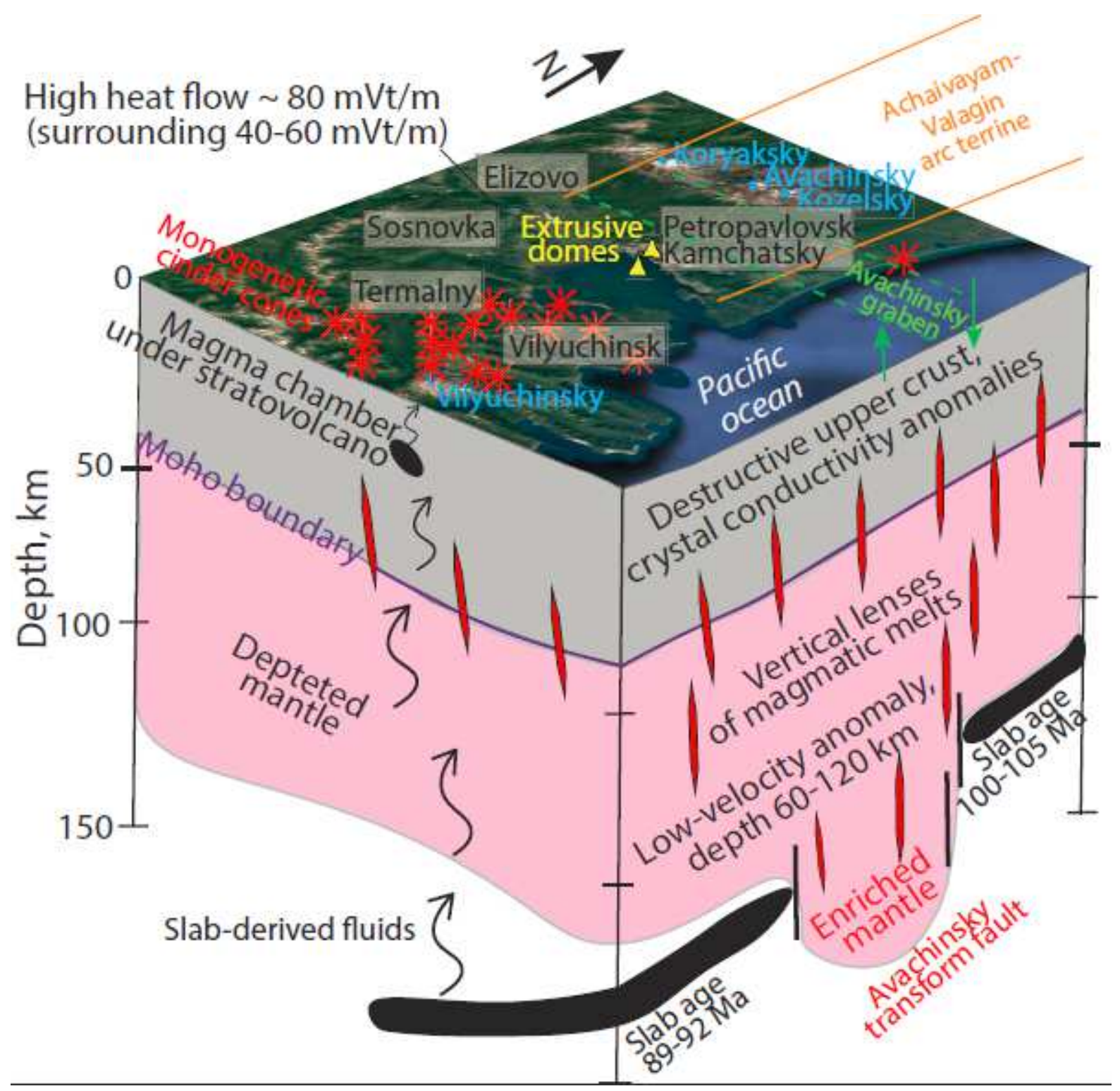

Figure 16

Schematic model of generation monogenetic volcanism in MPZ based on combination geophysical, geochemical and geological data. Position of Achaivayam-Valagin arc terrain in the basement of the north part of MPZ shown according to Cherkovich and Sukhov (2005). Crustal convey anomalies, and crustal structure are according to Aprelkov et al., 1999; Nurmahamedov, Sidorov (2019); Sheimovich, Sidorov, 2000; Loginov, Gontovaya (2020), heat flow (Sugrobov, Yanovsky, 1991), deep low-velocity anomaly (Gontovaya et al., 2010; Moroz, Gontovaya, 2018) Note: The designations employed and the presentation of the material on this map do not imply the expression of any opinion whatsoever on the part of Research Square concerning the legal status of any country, territory, city or area or of its authorities, or concerning the delimitation of its frontiers or boundaries. This map has been provided by the authors. 